\title{
Dos beaterios de Santa Rosa de Lima en Cusco: su historia y su arte ${ }^{1}$
}

\author{
Ewa Kubiak
}

\begin{abstract}
o
Este artículo se ha dedicado a los dos beaterios de Santa Rosa, que funcionaron en Cusco desde la década de los ochenta del siglo XVIII. Originariamente, existía un único recogimiento bajo la advocación de esta Santa, que reunía tanto a españolas, como a indígenas y a mestizas (según los documentos). Sin embargo, a resultas del conflicto racial y social surgido en los años ochenta de ese siglo, el beaterio se dividió en dos instituciones, que a partir de entonces tendrían sedes separadas. En la calle de San Andrés se ubicaría el beaterio de las españolas, y en un callejón situado junto al monasterio de Santo Domingo el destinado a las indígenas y mestizas. El presente artículo recrea la historia de ambas instituciones a base de la relación de José María Blanco, que data de 1834, y de varios documentos conservados, que proceden del siglo XVIII. Asimismo, se presentan datos estimativos referentes al interior de las capillas y a sus altares.
\end{abstract}

Palabras clave: beaterios, Beaterio de Santa Rosa, Cusco, época colonial, arquitectura colonial, arte colonial

\section{BRIEF HISTORY OF THE TWO BEATERIOS OF SANTA ROSA DE LIMA IN CUSCO}

\section{Abstract}

The article is devoted to two beaterios of Santa Rosa, which existed in Cusco from the 1880s. Originally, there was one recogimiento of the same dedication, which brought together both creole women (in this case referred to as españolas [Spanish women]) and Indian and Mestizo ones. However, as a result of a racial-social conflict in the eighties, a division into two institutions, which from then on had their separate headquarters. The beaterio of 'Spanish women' was in San Andres Street, while the one for the Indians and Mestizos - in the nook at the Monastery of Santo Domingo. The article recreates the history of both institutions based on accounts by José María Blanco from 1834 and several preserved documents from the 18th century. It also discusses some random information on the decoration of the chapels and their altars.

Keywords: beaterio, Beaterios of Santa Rosa, Cuzco, colonial period, colonial architecture, colonial art

Ewa Kubiak - Uniwersytet Łódzki / Instytut Historii Sztuki. E-mail: e.kubiak24@gmail.com, https://orcid.org/0000-0002-2740-0632 


\section{El beaterio como institución}

En los albores de la Edad Media, ya existían varios tipos de reclusión de carácter religioso junto a los monasterios. Se mantenían en un aislamiento suficiente como para que las personas, que sentían tal llamada, pudieran vivir en ellas al servicio de Dios, en silencio y devoción (Santa Teresa 1967: 230). A tenor de esta tradición, empezaron a crearse, en las postrimerías de la Edad Media y en la Edad Moderna, lugares de aislamiento destinados exclusivamente a las mujeres; en la Península Ibérica y en las colonias españolas, algunos de estos lugares fueron denominados beaterios. Se organizaban conforme a la regla religiosa elegida, eran supervisados espiritualmente por congregaciones específicas y, aunque no hubieran sido considerados oficialmente como monasterios, debían ser aprobados por las autoridades locales, con lo cual gozaban, en cierta medida, de carácter formal.

El primero en bosquejar una descripción de un beaterio en Cusco fue Ignacio de Castro en 1788. Escribió que "se recogen aquellas pobres, que ó por su calidad ó por su escasez de facultades son injustamente excluidas de los Monasterios y así compensan y satisfacen los deseos de consagrarse a Dios en Religión" (Castro 1978 [1788]: 54). No obstante, fue Donato Amado Gonzales quien nos ofrecería una definición más moderna, remitiéndose a las aclaraciones realizadas por Fortunata L. Herrera. Según él, el beaterio "surgió como reconocimiento y refugio, de voluntaria clausura, para las mujeres que querían vivir lejos de los desórdenes y excesos mundanos, dedicadas a la contemplación de la vida espiritual" (Amado Gonzales 2003: 225; véase también: Herrera 1920: 20). Las miembros de tales congregaciones recibían el nombre de beatas ${ }^{2}$, y llevaban una existencia muy similar a las de las monjas, sin serlo, aunque generalmente, como estas últimas, usaban hábitos y vivían recluidas formando comunidad. ${ }^{3}$ También prestaban votos de castidad, pobreza y obediencia, pero no eran votos perpetuos, a veces incluso solo tenían carácter privado. ${ }^{4}$

En Lima, se fundó el primero en 1558 y fue este el beaterio de Nuestra Señora de los Remedios, que no tardaría, -apenas tres años después-, en convertirse en el monasterio agustino de Nuestra Señora de Encarnación. A mediados del siglo XVIII, operaban en Lima cinco beaterios, al menos diez en Cusco y tres en Arequipa (Cantuarias Vargas 2002: 65). A pesar del elevado número de dichas instituciones, el beaterio, tal y como señala Kathryn Burns, ha sido un tema marginado por los investigadores. Hasta ahora, han aparecido escasos estudios sobre su historia, su funcionamiento organizativo y sus aspectos artísticos. La ínfima cantidad de documentos surgidos en estas instituciones ha contribuido a este estado de cosas: algunos de los que surgieron se dispersaron, y muchos de ellos, considerados insignificantes, fueron destruidos (Burns 2002: 87). Así que, hasta el presente, solo unos pocos autores han tratado la historia de los beaterios de Cusco. 


\section{Los beaterios de Cusco}

Entre el pequeño grupo de autores que se han dedicado al estudio de los beaterios en Cusco, nos encontramos con el historiador Fortunato L. Herrera, quien además fue el primero de todos ellos. Recopiló los datos diseminados concernientes a su historia y al funcionamiento de estas congregaciones. En su opinión, durante el período colonial en Cusco, se habrían fundado doce beaterios y, en los tiempos coetáneos al artículo del autor, es decir, a principios de la década de los 20 del siglo XX, aún seguían funcionando cinco en esa ciudad. Herrera recuerda que el primer beaterio fue instituido en Cusco por el padre jesuita, Juan Arias Vaca, antes de su muerte, acaecida el 29 de septiembre de 1672. El beaterio estaba destinado a mujeres indias "nobles, pobres y honradas" (Herrera 1920: 20). Ahora ya sabemos que las primeras beatas aparecieron en el siglo XVI: alrededor de 1550, Francisca Ortiz, una viuda de origen del País Vasco, decidió vivir conforme a la regla franciscana y, en la primera mitad del siglo XVII, después del año 1622, una viuda de Sevilla, Mari Díez de la Cueva Ojeda, habitaba en la ciudad de Cusco como beata franciscana. Kathryn Burns también menciona otros ejemplos tempranos de la existencia de beaterios en Cusco (Burns 2007: 82-85). A su vez el primer convento femenino de Cusco, el de Santa Clara, fue creado a resultas de la transformación del Beaterio de San Juan de Letrán, que funcionaba con anterioridad y que había sido fundado el 30 de abril de 1551 (Van Deusen 1990: 273-2925; Burns 2008 [1999]: 39-40) ${ }^{6}$.

El recogimiento femenino más importante y conocido en Cusco era el Beaterio de las Nazarenas, donde las mujeres congregadas vivían conforme a la regla carmelita. ${ }^{7}$ El primero en describirlas fue F. L. Herrera en su artículo ya mencionado, seguido de Jesús M. Covarrubias Pozo (1958: 280-287). K. Burns menciona el beaterio en su libro sobre las congregaciones femeninas en el Cusco colonial (2008 [1999]: 162-164), así como en su artículo, en el que aborda el tema del funcionamiento de estas instituciones (Burns 2002: 87). Por su parte, María Viñuales incluyó en un capítulo de su libro sobre el espacio urbano en Cusco durante el período colonial la historia del funcionamiento del Beaterio de las Nazarenas (2004: 181-189). ${ }^{8}$ Donato Amado Gonzales también dedicó a las "nazarenas" gran parte del artículo en que describe la historia de su segunda sede (2003: 213-236), ubicada en la parroquia de San Blas junto a la plaza que hoy lleva el nombre de Plaza de las Nazarenas. Otra comunidad muy importante en Cusco fue la del Beaterio del Carmen en la parroquia de San Blas, situada frente a la iglesia parroquial. Se desconoce la fecha exacta de su fundación, pero se nombra por vez primera en fuentes procedentes de los años comprendidos entre 1670 y 1690 (Cuzco 16891982 [1689]: 230-231; Kubiak 2020 [en imprenta]; véase también: Kubiak, Gómez Huacso 2019: 95-126). 


\section{El culto de Santa Rosa de Lima en Cusco}

Rosa de Santa María fue la primera santa de América. Nació en 1586. Provenía del linaje de los Oliva y se la bautizó con el nombre de Isabel Flores. Fue ya como terciaria dominicana, cuando tomó los nombres de Rosa de Santa María. Murió en 1617, fue beatificada en 1668 y canonizada tres años después, en 1671 (Busto Duthurburu 2016 [2006]: 19, 325, 336). Su vida de castidad y ascetismo, entregada en cuerpo y alma a la oración, se ha convertido en un modelo a seguir para muchas mujeres, tanto de las clases humildes como de las pudientes. Rosa mostró cómo alcanzar la santidad sin unirse a una orden religiosa, eligiendo únicamente un estilo de vida modesto y dedicado a la oración. De acuerdo con el testimonio de su confesor, Leonard Hansen, Rosa organizaba sus quehaceres semanales de acuerdo con las instrucciones del místico y teólogo Luis de Granada. Asimismo, para la santa americana, ideal y ejemplo a imitar fue Santa Catalina de Siena (1347-1380), a quien la llamaba "madre" y la rodeaba de una veneración especial (Van Deusen 2017: 25).

El culto a Santa Rosa de Lima nació en la capital del Virreinato del Perú poco después de su muerte, incluso antes de su canonización, y como escribe Ybeth Arias Cuba: "su devoción se extendió de manera rápida en el orbe católico y desde luego en los territorios de la Monarquía Hispana. La creciente devoción motivó la celebración de magnas fiestas por la beatificación de la santa limeña y la producción y reproducción de numerosas representaciones escritas (hagiografías, sermones, relaciones de fiesta, novenas, comedias de santos, entre otros) y representaciones visuales (pinturas, grabados, esculturas, retablos)" (Arias Cuba 2016: 81). Juan Meléndez (1671) nos ha legado un relato muy interesante del proceso de beatificación de la santa en Lima. El autor describe la procesión con la figura de Santa Rosa por las calles de la ciudad, tras la imagen de San Catalina de Siena (1671: 16), además de presentar con todo detalle el séquito que acompañaba a las figuras: los frailes dominicos ataviados con "dalmáticas de finissimos brocados de los mejores ornamentos de nuestra ponderosa sacristía", los acólitos, que marchaban junto a ellos, engalanados con "varios y vistosos roquetes tirados de diversas telas ricas, unas blancas, y otras carmesíes, con fluecos de seda, y oro co[n] q[ue] adulavan la vista"; velas encendidas iluminaban la procesión y ante la figura de Santa Rosa se juntaban doce niñas vestidas con los hábitos de las beatas dominicanas, tocadas con coronas de rosas y ramos de flores en las manos (1671: 30 v.; véase también: Van Deusen 2017: 44). Según Ybeth Arias Cuba, la imagen de Santa Rosa fue paseada repetidamente por las calles de Lima en tiempos de crisis a guisa de "persecución de temblores y pestes" (2019: 237), y si bien es verdad que, en 1678, tras la procesión de las reliquias de Santa Rosa, se produjo un nuevo temblor, este presentó un carácter mucho más atenuado (2019: 354). Según Ramón Mujica Pinilla "en varias ocasiones se sacaron sus reliquias en procesión por Lima para poner fin a los temblores" (Mujica Pinilla 
2005 [2001]: 202; ver también Peralta 1860: 744). En México, el culto a la Santa Rosa de Lima se remonta a los finales del siglo XVII (Arias Cuba 2019: 382).

Santa Rosa era limeña. Nació, vivió humildemente en la capital del virreinato y en ella murió. Sin embargo, también en Cusco encontramos numerosas huellas de la devoción a la santa. Los habitantes de la ciudad creen que, aunque nació en Lima, también es una santa cuzqueña porque fue concebida en la capital andina de los Incas (Mujica Pinilla 2005 [2001]: 209). Incluso antes de $1688^{9}$, se escribió un sermón sobre Santa Rosa de Lima, compuesto por Juan de Espinosa Medrano y predicado en la ciudad de Cusco (Espinosa Medrano 2011 [1695]: 249-256; Vélez Marquino 2010: 65; Perilli 2011: 19-28; Mujica Pinilla 2005 [2001]: 199). En este panegírico, el autor no solo ensalzaba las cualidades de la santa y su posición en el panteón de los santos, sino que también aludía a episodios individuales de su vida que habrían influido en la iconografía de Rosa de Lima. Uno de los motivos más famosos es la escena del (desposorio místico) con el Niño Jesús, que fue poéticamente interpretado por Espinosa Medrano. Asimismo, testimonio temprano del culto a la santa lo constituye la figura de Santa Rosa presente durante la procesión del Corpus Cristi en una de las pinturas de la famosa serie de la Iglesia de San Ana, que presenta a determinadas parroquias y ordenes participantes de la festividad (fig. 1). (Arias Cuba 2019: 415). En la representación, su imagen se yuxtapone a la de Nuestra Señora de la Almudena. Según la opinión de muchos investigadores, es harto significativa la representación de estas dos figuras ensambladas en una procesión. Rosa vendría a representar el mundo criolloindio del virreinato del Perú, mientras que la Virgen de la Almudena constituiría una evocación madrileña y recordaría la presencia de la corona española en el lejano Cusco. La vecindad de las dos imágenes puede interpretarse como "un contrapunto simbólico entre ambas ciudades" (Wuffarden 2008: 61; véase también Wuffarden 1996: 73; Dean 2002 [1999]: 93). ${ }^{10}$ Diego de Esquivel y Navia describe otras dos procesiones con imágenes de Santa Rosa de Lima entre 1740 y 1746 (1980 [c. 1749], II: 273, 374). Muy tempranamente aparecieron en la región cusqueña iglesias bajo su advocación y nombres de lugares también relacionados con la santa, así como sus imágenes y una cofradía religiosa dedicada a su culto, establecida en la Iglesia de Santo Domingo en Cusco. Ya en la década de 1680, las iglesias de Santa Rosa en Chuquibamba y en Nuñoa son mencionadas con motivo de unas visitas eclesiásticas (Wuffarden 2008: 45). A su vez, se hace referencia por primera vez a la "Cofradía de Santa Rosa fundada en el Convento de Predicadores" en un documento de 1678 (ARC, 1678, f. 110). Posteriormente, en 1701, Don Lázaro Ramos declara en su testamento "ser cofrade" en siete hermandades religiosas, entre las cuales "en la Cofradía de Nuestra Señora de Santa Rosa” (ARC, 1701, f. 186 r.). Las imágenes de la santa se nombran en contratos, testamentos e inventarios desde fines del siglo XVII. En 1694, Marcos de Rivera "maestro pintor" de Cusco "se obliga hacer y pintar 13 lienzos de diferentes hechuras de Santos", entre otros también la imagen de "Santa Rosa con el niño Jesús que le quita la corona de espinas y clavos y pone otra de rosas" (ARC, 1694, f. 186 r.) ${ }^{11}$. En 1716 Doña 
Agustina Choque Sisa "deja a su nieto un lienzo de Santa Rosa" (ARC, 1716, f. 314r.). Igualmente se puede hallar información sobre las imágenes de la santa en los testamentos de otras personalidades cuzqueñas: Agustín Bravo de Paredes de 1772 ("más otro Lienzo de Sa.[n]ta Rosa”, ARC, 1772, f. 43v.) o Martina Chiguantopa de 1813 r. ("Lámina con la representación de Santa Rosa", ARC, 1813, f. 529). También en los templos de Cusco había, y todavía las hay, representaciones de la santa. Por supuesto, las series más famosas son las que se conservan en las iglesias conventuales de Santo Domingo y Santa Catalina de Sena (figs. 2-3). ${ }^{12}$ Imágenes de Santa Rosa también están incluidas en los inventarios de la iglesia el Hospital de los Betlemitas (1727 y 1738) (ARC, 1727, f. 8v.; ARC, 1738, f.54r. y f.56v.), así como "Una reliquia de Santa Rosa con su Peaña y sol De Platta" se halla mencionada en el inventario de la Iglesia de los Jesuitas de Cusco de 1767 (AGN, 1767-1768, f.29r.), y en la Iglesia de San Jerónimo en 1819 llegó a existir una "una capilla de Santa Rosa" (ARC, 1819). Como se puede colegir de las numerosas fuentes iconográficas y escritas aquí presentadas, el culto a Santa Rosa se desarrolló en Cusco desde la década de los 80 del siglo XVII, fortaleciéndose paulatinamente en el transcurso de los siglos XVIII y XIX. ${ }^{13}$

\section{Los Beaterios bajo la advocación de Santa Rosa de Lima en la ciudad de Cusco}

La primera mención acerca del beaterio dominico en Cusco data de 1709. El 16 de enero del año en cuestión, fue firmado un contrato entre el superior de la institución y el maestro ensamblador Diego Chapana con el objetivo de ampliar el altar de la capilla perteneciente a dicha congregación. Este acuerdo ha sido referido por Jorge Cornejo Bouroncle en su libro titulado Derroteros de arte cuzqueño (1960: $262) ;{ }^{14}$ sin embargo, la posibilidad de familiarizarme personalmente con el contenido de dicho documento me ha permitido mostrar el contexto de ese contrato de un modo más amplio (ARC, 1709, ff. 436r.-437 v.).

El contrato se celebró entre Petrona Rosa, la superiora de Beaterio de Santa Rosa y el maestro Don Diego Chipana. Del contenido del documento se deduce que el artista era de origen indígena, que provenía de la parroquia "del hospital de los naturales" y que estaba sometido al cacique don Francisco Paucar. Este fue el motivo por el cual don Gerónimo de Alegría y Carvajal, que ostentaba en Cusco el cargo de Protector de los Naturales, sería convocado como testigo del acto legal, Tomás de Molina y Perales como traductor del quechua, la lengua de los nativos y, a su vez, Don Joseph Corimanya "[...] ynga Maestro barbero" (ARC, 1709, f. 436r.) actuaría como garante. En el contrato, el artista se comprometía a agrandar el altar existente de un nicho con cuatro más, para crear así un retablo de cinco calles. Las obras debían realizarse según el esbozo presentado adjunto. El contrato estipulaba que la ampliación del altar estribaría en agregar un número adecuado de columnas, junto con sus capiteles, de modo que formaran un altar completo. El contrato establecía 
un pago de 180 pesos (ARC, 1709, f.436r.). Por desgracia, el contrato no mencionaba ni el domicilio de la congregación ni la advocación bajo la cual se hallaba; tan solo se especificaba su dependencia de una orden de predicadores: "el [...] beaterio del Convento de Santo Domingo" (ARC, 1709, f.436).

Fortunato L. Herrera identificó en Cusco dos congregaciones bajo la advocación de Santa Rosa de Lima, sirviéndose, en calidad de fuente, del diario de del presidente Luis José de Orbegoso y Moncada Galindo del año 1834, redactado por José María Blanco. ${ }^{15} \mathrm{~A}$ tenor de la información extraída del mismo, Herrera escribe que el primer beaterio de Santa Rosa de Lima reemplazó una institución que había funcionado con anterioridad en el mismo lugar, fundada en 1760 por el padre jesuita Manuel Pintos. Se trataba de una comunidad femenina que se regía según la regla carmelita. Su establecimiento en 1760 había sido posible gracias a la generosidad del párroco de la localidad de Pisac, José Arizabalaga, y de dos residentes de Cusco, Domingo Ledo y Agustín Arriaga. Cuando la orden de los jesuitas fue expulsada en 1767, ante la carencia de recursos económicos para mantener la comunidad, el beaterio se convirtió en un espacio destinado a hacer ejercicios espirituales y de esta manera funcionaría hasta 1795. En ese mismo año, los frailes dominicos, Pedro Mosqueira y Juan Hurtado, en apoyo del párroco de Azángaro Matías Alday, así como los doctores Juan Munive y Moscoso, Fernando Trelles y Félix Colonga enviaron una solicitud al virrey del Perú, Francisco Gil de Taboada y Lemus, a fin de que les fuera concedido el permiso para abrir una congregación bajo la advocación de Santa Rosa de Lima, según la regla dominicana, la cual fue concedida (Herrera 1920: 23; Blanco 1974 [1834]: 249).

J. M. Blanco también hace referencia a la división de la institución. Según él, hubo conflictos internos entre las integrantes españolas e indígenas de la comunidad, en razón de los cuales se produciría su separación "para cortar esta estúpida antipatía [...]", que no coincidía con la moral de la vida monástica. Las beatas españolas permanecieron en la antigua sede de la congregación en la calle de San Andrés, mientras que las beatas indígenas se mudaron a la calle Mutcapuquio, en cuya nueva sede, estuvieron bajo un monasterio dominico (Blanco 1974 [1834]: 249). Podemos mantener ciertas dudas en cuanto a las fechas que Blanco nos proporciona, en la década de 1830, en relación con el siglo XVIII, pero los datos concernientes a la división de la institución $\mathrm{y}$ al domicilio de los beaterios son del todo fidedignos. Blanco incluso podría haberlos visitado en persona. El domicilio de dichos beaterios también se ve confirmado por un mapa incluido en el "Atlas geográfico del Perú", publicado en París en 1865, bajo la dirección de Mariano Felipe Paz Soldán. En el plan topográfico de Cusco, elaborado por el ingeniero del estado Federico Hohagen, ambos beaterios estaban marcados: en el número 17, nos encontramos con el Beaterio de Santa Rosa (con capilla) y, en el número 19, con el Beaterio de Ahuacpinta ó Mutcapuccio. ${ }^{16}$ (fig. 4)

La historia de los beaterios dominicos, basada en el relato de Blanco, se ha convertido en lectura obligatoria dentro de la modestísima bibliografía (Cosio 
1918: 49; Zárate 1921; 46-47; Viñuales 2004: 180-181; Viñuales 2019: 90) sobre este tema, aunque, como ya se dijo, las fechas proporcionadas por este autor carecen de precisión. Cabe, por ende, establecer que ambos beaterios habían funcionado antes de ese tiempo, lo cual se vería corroborado por un documento, hasta ahora inédito, de 1788. Muestra una fecha anterior al momento del fraccionamiento de la institución indicado por Blanco; por lo tanto, la disgregación y posterior creación del primer beaterio de Santa Rosa debería haber tenido lugar antes de 1788, o incluso de 1780, según se colige del contenido del documento (AAC, 1788, pp. 1-4).

Este escrito no es otra cosa que la solicitud de la superiora del beaterio de Santa Rosa, la hermana Juana del Sacramento, para realizar el traslado de la figura de San Juan Bautista junto con su altar del "[...] Beaterio del Callejón del Convento de Santo Domingo" al "[...] Beaterio de mi Patrona de Santa Rosa, en la calle de San Andrés, donde ha fundado el Beaterio de las Españolas" (AAC, 1788, p. 1).

Este documento viene a confirmar, igualmente, la discordia surgida entre ambas instituciones. En él, Juana del Sacramento relacionaba cómo, ocho años atrás, había encargado hacer una renovación por su propia cuenta y cómo después trasladó la figura del "Glorioso Patriarca Señor San Josef” al beaterio que se hallaba junto al monasterio dominico. La labor artística fue ejecutada por el maestro escultor Don Romualdo Xara, lo que este mismo confirmaba en una declaración adjunta. A saber: que, aproximadamente nueve años antes, había tallado una figura de San José de un metro y medio de altura más o menos ${ }^{17}$ para el beaterio de Santa Rosa, por la cual la hermana Juana del Sacramento le pagó 7 pesos. La superiora de la congregación declaró que ella misma había corrido con los gastos y que, ni las "monjas" del beaterio para las cuales estaba destinada la escultura, ni los padres dominicos contribuyeron a ellos, ni ayudaron de manera alguna a la renovación de la imagen del santo. También hacía alusión a que la figura fue traída por una mujer indígena llamada Juana, quien la había encontrado en una pequeña capilla, donde se la veía tratada con desprecio, desidia y abandono. Además, el altar, en el que se había instalado la imagen de San José, habría sido adquirido por el padre Francisco Juan Hurtado y por el doctor Don José Quintanilla, ${ }^{18}$ quienes pertenecían al grupo de fundadores del beaterio español (Santa Rosa) en la calle de San Andrés. El retablo era pequeño y de calidad mediocre, por lo que Juana del Sacramento habría encargado la ampliación del altar con el pago adicional de 7 pesos. En el momento de escribir la petición, según Juana del Sacramento, la figura de San José no gozaba del culto debido, ni de misas celebradas en su honor, motivos por los cuales la beata solicitaba el traslado inmediato de la imagen al nuevo beaterio dedicado a Santa Rosa (AAC, 1788, pp. 1-4). Por desgracia, ignoramos cómo se resolvió el caso.

Es evidente que la superiora del beaterio de españolas de Santa Rosa no se había formado una buena idea sobre la congregación terciaria de muchachas indígenas con sede cercana al convento de los frailes dominicos. Les reprocha su negligencia en la dispensa del culto debido a la imagen de San José, por lo que exige que le sea 
devuelta la estatua renovada por ella. En el lado opuesto de la balanza, cabe recordar que Rosario Zarate alude brevemente a una de las hermanas de la congregación de indias y mestizas, la madre Ángela, quien se distinguía por sus excepcionales virtudes y sabiduría y con quien, no solo personas simples, sino también dignatarios de la iglesia se aconsejaban. Al parecer, la Madre Ángela era muy apreciada y recababa su fortaleza espiritual gracias a la adoración del Santísimo Sacramento (Zárate 1921: 47).

El último documento que hallé, donde se vierte alguna información sobre el beaterio de Santa Rosa, es un fragmento de la visita, llevada a cabo en cuatro beaterios, en el año 1826: Nazarenas, Carmen de San Blas, Belén y, precisamente, Santa Rosa. La visita de este último fue descrita en una página entera. Por lo visto, la superiora, la hermana Tadea del Santísimo Sacramento, informaba en una carta dirigida al administrador de la iglesia (gobernador eclesiástico) que la congregación carecía de cualquier recurso estable de subsistencia: "le pase una razón individual de las Rentas de este Recogim. [ien] ${ }^{\text {to }}$ digo a V.S. que son ningunas absolutam. [en] te pues las Beatas q. $[u]^{\mathrm{e}}$ que quieren recogerse, lo mismo q. $[\mathrm{u}]^{\mathrm{e}}$ algunas Seglares, todas se mantienen a expensas de su labor, sin que el Beaterio pueda ministrarles el mas pequeño auxilio por carecer de fondos ó principales. Y si bien se recogen Sesenta p. [eso] ${ }^{\mathrm{s}} \mathrm{de}$ una obra pía Cituada en el Barrio del Hospital" (AAC, 1826). Al parecer, el dinero recaudado se gastaba en misas por las almas de mujeres de la comunidad, que se celebraban todos los jueves. La liturgia era acompañada de un escenario apropiado, por lo que se compraba cera, se pagaba a los músicos y "demás necesidades". En 1826 , se agrupaban en el beaterio diez hermanas, y treinta y una mujeres y niñas sin profesar (AAC, 1826).

\section{Fin de la existencia de los beaterios: el terremoto de 1950}

El terremoto que sacudió Cusco el 21 de mayo de 1950 pondría punto final a la existencia de los edificios del siglo XVIII pertenecientes a ambos beaterios. Sus capillas y los edificios tenían una forma simple, estaban hechos de adobe y, ante semejante cataclismo, sufrieron una total devastación. En el antiguo beaterio situado junto al convento de los frailes dominicos, se estableció una congregación de dominicas de Santa Rosa de Lima, en la primera mitad del siglo XX (1919), que existió durante 8 años sin la aprobación oficial, la cual recién la recibieron tan solo en 1927. Las hermanas abrieron en ella un centro educativo; y esta escuela, inaugurada a la sazón, sigue en activo bajo el nombre de Colegio de Santa Rosa de Lima en Cusco (https://www.santarosa.edu.pe/institucion/nuestra-historia [fecha de acceso: 24.08.2019]).

El terremoto de 1950 resultó ser extremadamente destructivo para este lugar. Tal y como George Kubler lo describe, los edificios del antiguo beaterio de la calle Ahuacpinta se vieron reducidos a ruinas, "[...] los humildes edificios de adobe de la iglesia y del convento quedarán totalmente destruidos por el terremoto. Sólo se 
salvaron el altar, el púlpito y las puertas de la iglesia" (Kubler 1953: 28). Al principio, se erigió un edificio destinado a la residencia de las monjas, y debido a la falta de capilla, para la liturgia y oración se utilizaba una de las celdas para esos fines. En los planes de reconstrucción relacionados por Kubler, se presenta el proyecto de construcción de un nuevo edificio escolar (Kubler 1953: 28), que se implementaría con éxito como se ha comentado anteriormente.

La capilla fue reconstruida en 1954 (figs. 5-6) (dicha fecha aparece encima del portal). En el interior de la nueva capilla, se pueden admirar tanto el altar conservado del siglo XVIII (fig. 7) con cinco figuras que representan a los santos (entre ellos San José y Santa Rosa de Lima) como una colección de pinturas coloniales. Existen también varios lienzos, en posesión del colegio, que representan a la patrona del antiguo beaterio, Santa Rosa de Lima, en los cuales se ven trazadas imágenes individuales de la santa, así como escenas que muestran episodios de su vida, por ejemplo, su desposorio místico con el Niño Jesús (fig. 8). La capilla también está decorada con imágenes de María, representaciones de Cristo y otros santos. Se trata tanto de advocaciones que gozaron de difusión universal en el siglo XVIII bajo la égida de la iglesia católica, por ejemplo, la Virgen Dolorosa (fig. 10) o la Tota Pulchra (o Inmaculada Concepción) (fig. 11), como de imágenes típicas de Hispanoamérica, el Señor de Burgos (fig. 12), o de representaciones completamente locales como el Señor de los Temblores (fig. 13). Entre los santos puedes encontrar: a Santo Domingo, a Santa Catalina de Siena (Desposorio místico de Santa Catalina o Estigmatización de Santa Catalina, fig. 14), a San Cristóbal, a San José, a Santa Juliana, a Santa Gertrudis o a San Juan Bautista. Asimismo, podemos observar que la pintura que representa el desposorio místico de Santa Rosa del beaterio de Cusco tiene una composición similar a la de otro lienzo instalado en el Monasterio de Santa Rosa de Santa María en Lima. La representación de Lima proviene del siglo XVIII, es anónima, pero también se incluiría en el marco artístico de la escuela cusqueña. (fig. 9). De igual modo, en la estigmatización de Santa Catalina de Siena del beaterio de Santa Rosa de Cusco no se hace difícil hallar paralelismos con otras obras pictóricas del Virreinato del Perú. Es una composición recurrente en casi todos los ciclos episódicos de la vida del santo; por ejemplo, entre los lienzos del Monasterio de Santa Catalina de Siena de Córdoba (figs. 15-16) o en el Monasterio de Santa Catalina de Siena de Arequipa (fig. 17). En este último caso, es posible indicar las fuentes gráficas que inspiraron las representaciones pictóricas. Me refiero a dos grabados en cobre: el primero salió del taller de Jean Leclerc (activo 1573-1627) y fue utilizado como una de las ilustraciones del libro titulado D. Catharinae Senensis Virginis SSmae Ord. Praedicatorium Vita ac miracula selectiora formis aeneis expressa $(1607)^{19}$ (fig. 18); el segundo fue elaborado por Pedro de Jode I (1565-1639), según idea y dibujo de Francesco Vanni (c. 1563-1610), (figs. 19-20), convirtiéndose en una de las representaciones del ciclo gráfico de la vida de Santa Catalina en una serie de estampas sueltas publicado bajo el título Vita, mors, et miracula quaedam selecta B. Catherinae Senensis (1597). ${ }^{20}$ 
Donde un día estuviera el segundo beaterio de Santa Rosa, en la calle de San Andrés, hoy se encuentra el Instituto Superior Pedagógico Público Santa Rosa, una institución secular que reemplazó a la escuela dirigida hasta principios de la década de 1940 por las Hermanas Misioneras Dominicas del Rosario (http://www. portalweb.santarosacusco.edu.pe [fecha de acceso: 24.08.2019]). Los edificios del antiguo beaterio también fueron destruidos durante el terremoto de mediados del siglo XX. La evidencia de las antiguas funciones del beaterio se conserva parcialmente en el interior de la antigua capilla. En 1920, Rosario Zarate ya describía su mobiliario: "[...] existe en esta Capilla la bella imagen de la Santa Patrona, de anónimo artista cuzqueño" (1921: 46). El autor también mencionaba dos lienzos, que le parecieron más interesantes o más valiosos: “[...] lienzos: Virgen del Carmen y la Eucaristía de Santo Tomás de Aquino rodeado de los Doctores de la Iglesia” (Zárate 1921: 46). Tras el terremoto en 1950, se escribieron inventarios para ambos beaterios de las imágenes rescatadas de la catástrofe, catalogándose un total de 73 imágenes pertenecientes al antiguo beaterio de Santa Rosa de la calle San Andrés y 80 descripciones de lienzos de la capilla de la congregación terciaria de Santo Domingo la calle Ahuacpinta. Desafortunadamente, solo algunas de las obras enumeradas en los inventarios han sobrevivido hasta nuestros días. ${ }^{21}$

\section{Conclusiones}

La sociedad del Cusco siempre se ha visto dividida en un sector criollo y un sector mestizo-indígena. Si bien se han dado momentos en la historia de la ciudad donde la existencia de ambos grupos confluye, por lo general la fragmentación ha sido muy clara. No es de extrañar entonces que las españolas y las indígenas que vivían bajo un mismo techo no fuesen capaces de entenderse. En una relación de 1689 leemos que los beaterios estaban destinados a un grupo social específico; por ejemplo, en la parroquia de San Blas dos de ellos eran asignados a "españolas" y tres a "indias". Las postrimerías del siglo XVIII fueron un momento especial en la historia de Cusco y todo el Perú. Debe recordarse que la rebelión de Tupac Amaru (1780) tuvo lugar en el contexto de la vida religiosa cotidiana y que la élite de la nobleza indígena de Cusco no apoyaba al líder del levantamiento. En el caso de los beaterios de Santa Rosa, el conflicto racial influyó definitivamente sobre la división de las instituciones. La convivencia entre "españolas" e "indias" se hizo imposible. En 1793, cuando Joseph Hipólito Unanue describe los beaterios de Cuzco, a este de Santa Rosa asignado a las criollas le denomina conforme a la advocación de "Santa Rosa"; en cambio, a este destinado a las indígenas le llama beaterio de "Santo Domingo de Naturalas" (Unanue 1793: 246). 

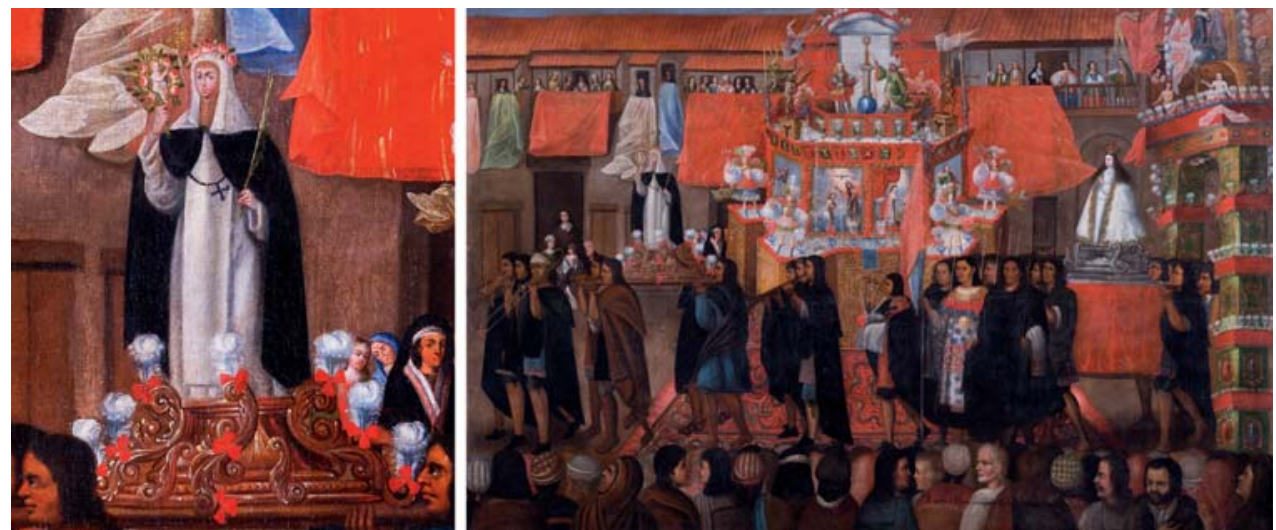

Fig. 1. Cofradías de Santa Rosa y "La Linda" o Virgen de Almudena, anónimo, serie del Corpus Christi, c. 1675-1780, óleo sobre el lienzo, Museo de Arte Religioso, Cusco, Perú, fot. Ewa Kubiak 2018.

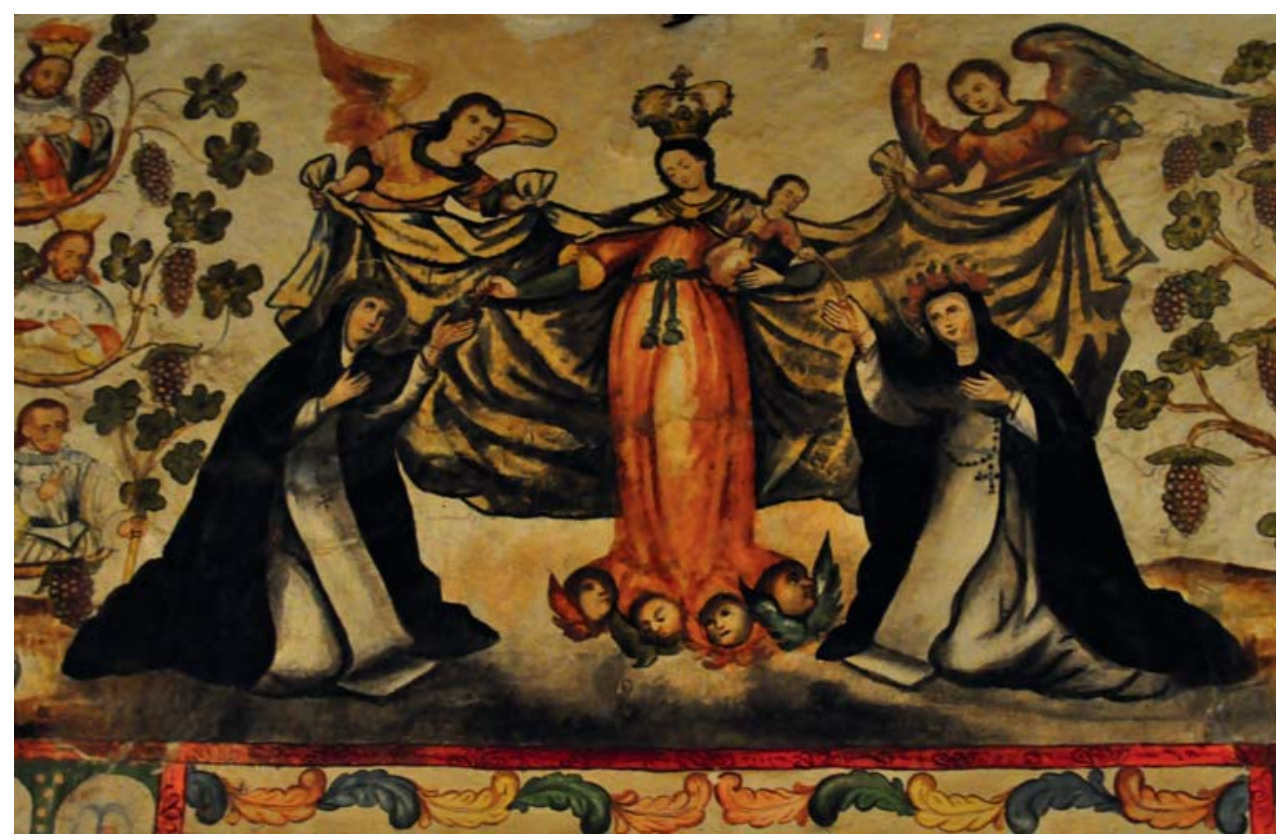

Fig. 2. Virgen del Rosario con Santa Catalina de Sena y Santa Rosa de Lima, anónimo, finales del siglo XVIII, la sala capitular del Convento de Santa Catalina del Cusco, fot. Ewa Kubiak 2018. 


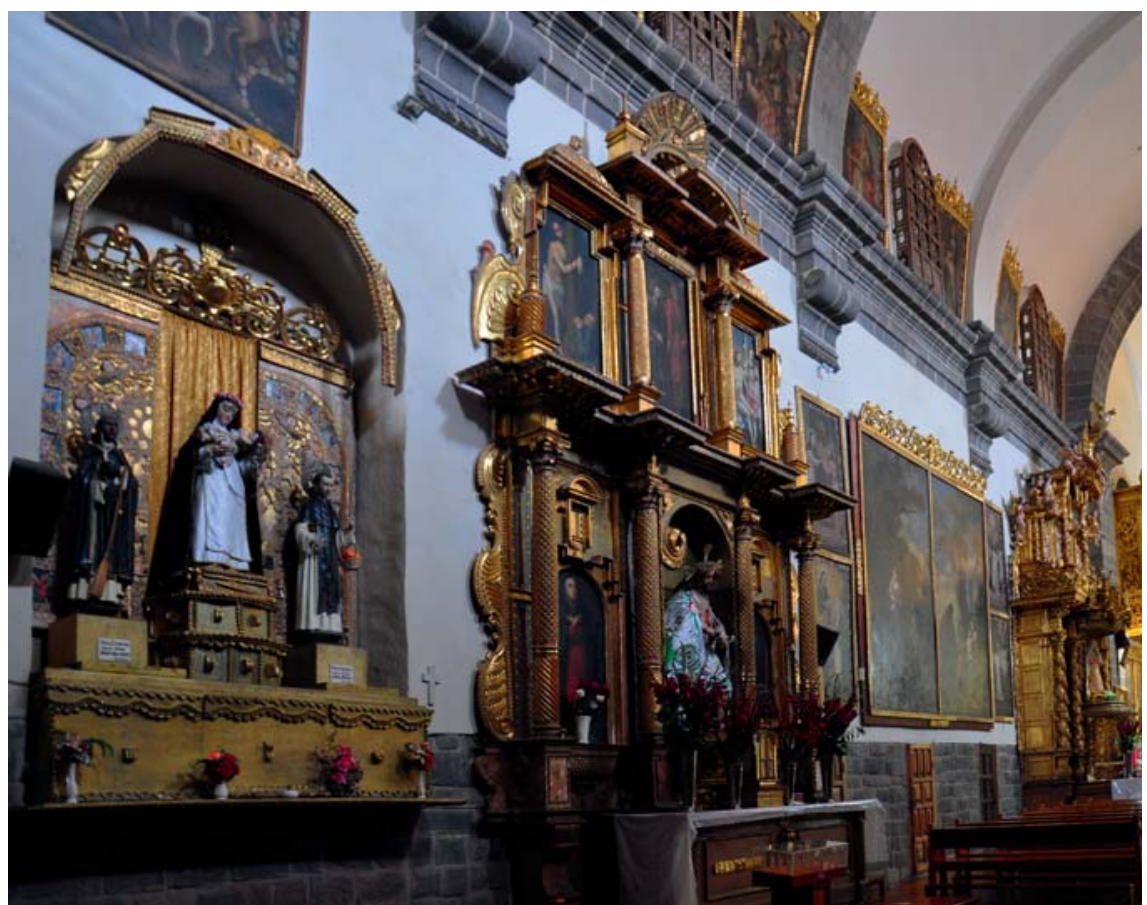

Fig. 3. Santa Rosa de Lima, escultura, interior de la iglesia del Convento de Santa Catalina de Sena, Cusco, fot. Ewa Kubiak, 2018.

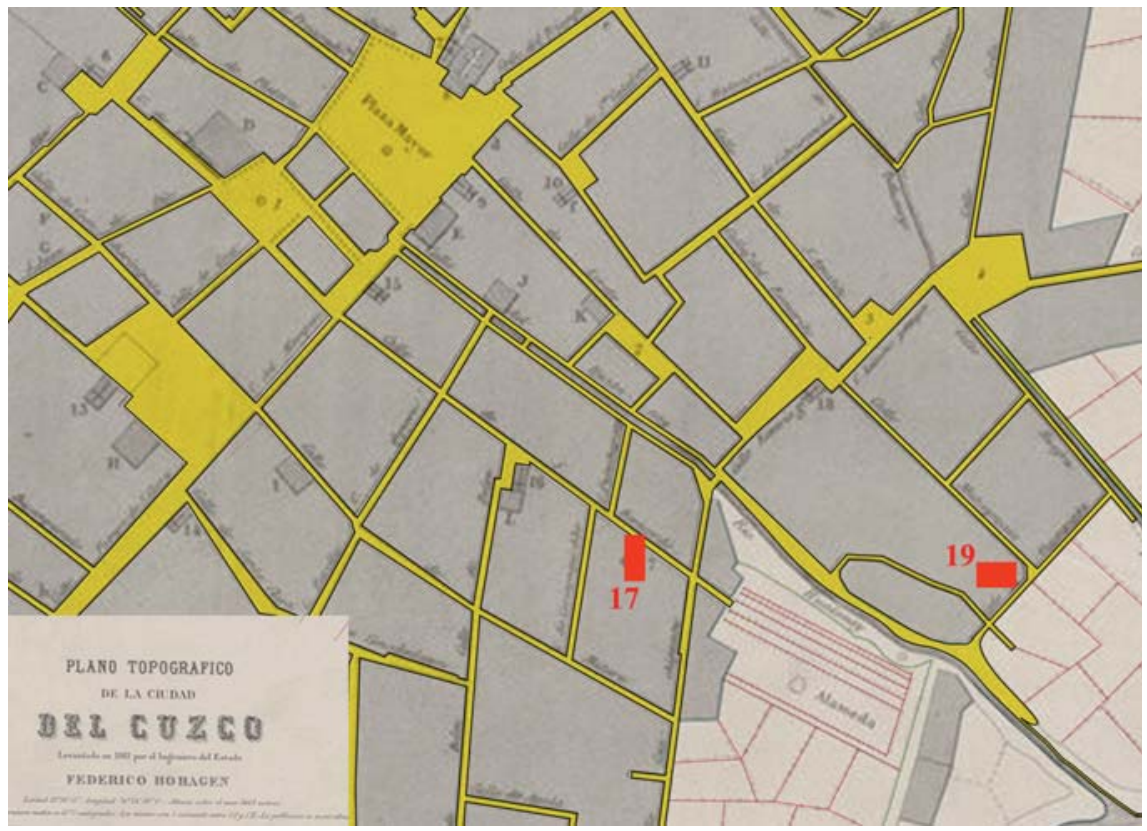

Fig. 4. El mapa de Cusco elaborado por Federico Hohagen incluido en el "Atlas geográfico del Perú" (Paz Soldán 1865) adaptado por Ewa Kubiak y Bartek Smoczynski. 


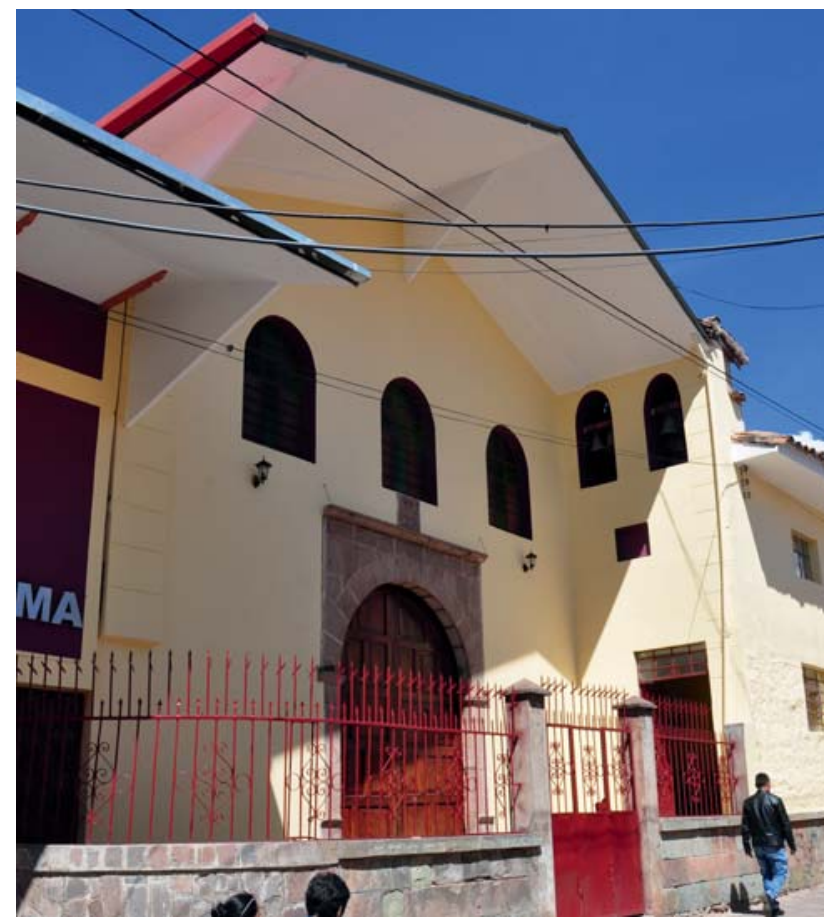

Fig. 5. Fachada de la nueva capilla del Colegio de Santa Rosa de Lima en Cusco, que sustituyó la antigua capilla del Beaterio de Santa Rosa "Ahuacpinta", 1954, fot. Ewa Kubiak 2018.

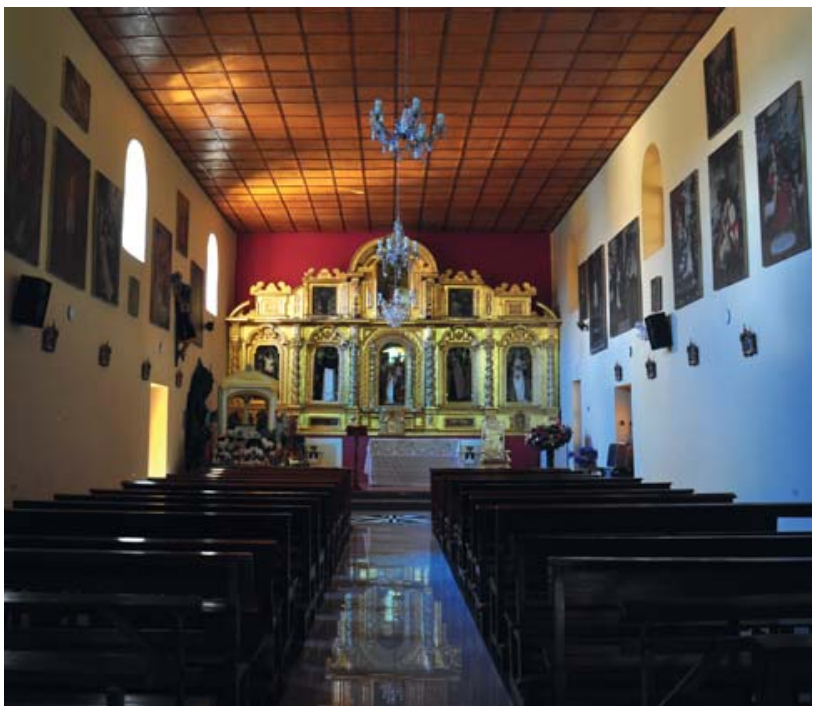

Fig. 6. Interior de la nueva capilla del Colegio de Santa Rosa de Lima en Cusco, que sustituyó la antigua capilla del Beaterio de Santa Rosa "Ahuacpinta", 1954, fot. Ewa Kubiak 2018. 


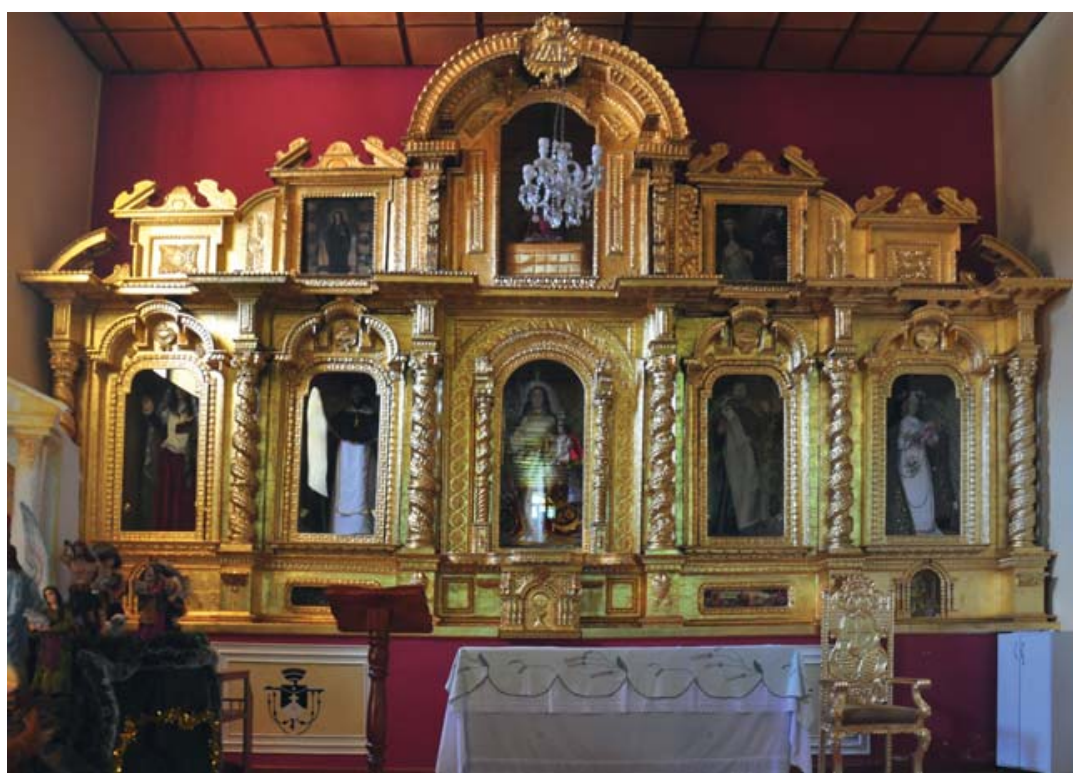

Fig. 7. Altar del antiguo Beaterio de Santa Rosa "Ahuacpinta", actualmente en la Capilla del Colegio de Santa Rosa de Lima en Cusco, anónimo, el siglo XVIII, fot. Ewa Kubiak, 2018.

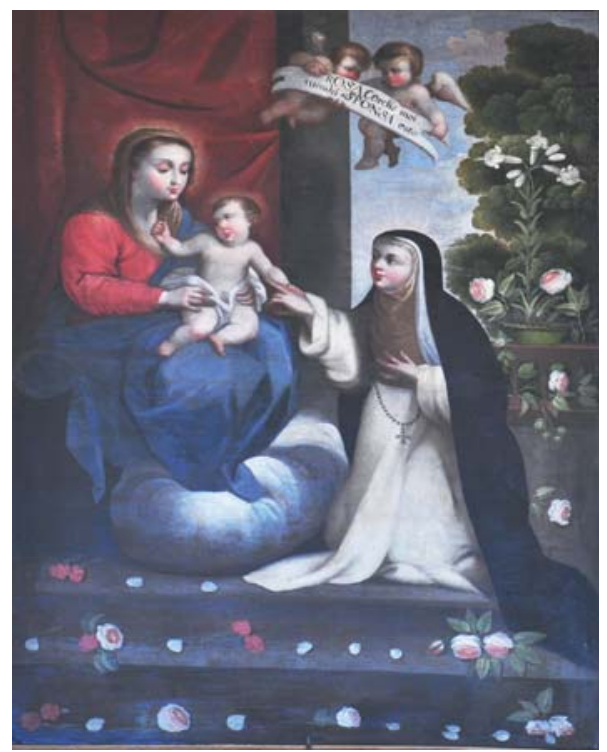

Fig. 8. Desposorio místico de Santa Rosa de Lima con el Niño Jesús, anónimo, segunda mitad del siglo XVII, Capilla del Colegio de Santa Rosa de Lima en Cusco, fot. Ewa Kubiak, 2018.

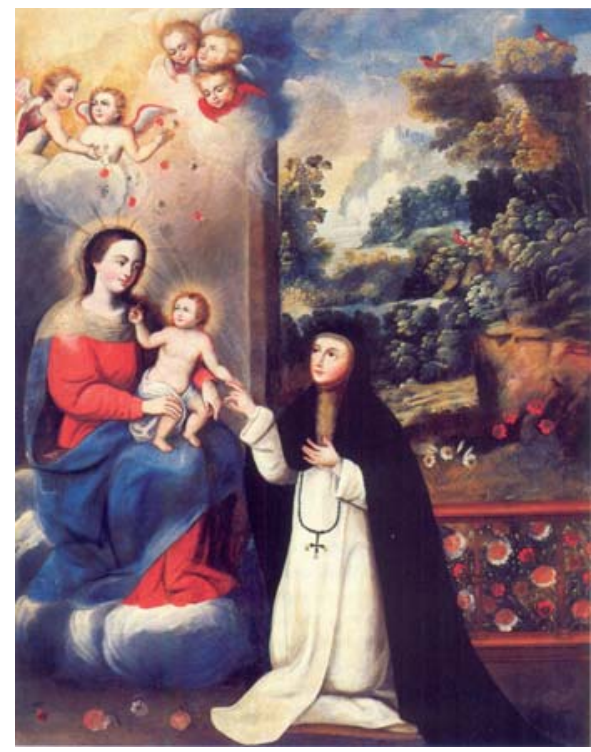

Fig. 9. Desposorio místico de Santa Rosa de Lima con el Niño Jesús, anónimo, siglo XVIII, Monasterio de Santa Rosa de Santa María, Lima (Mujica Pinilla 1995: 121). 


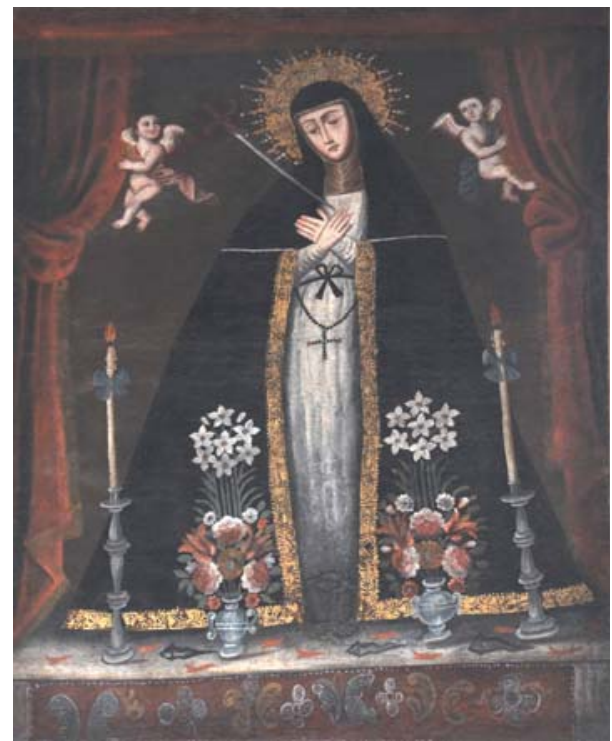

Fig. 10. Virgen Dolorosa, anónimo, siglo XVIII, Capilla del Colegio de Santa Rosa de Lima en Cusco, fot. Ewa Kubiak, 2018.

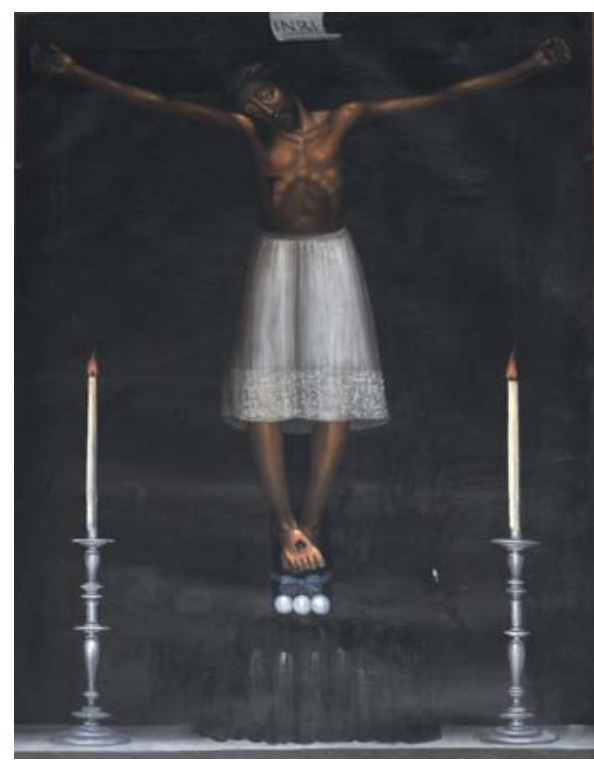

Fig. 12. Señor de Burgos, anónimo, anónimo, siglo XVIII, Capilla del Colegio de Santa Rosa de Lima en Cusco, fot. Ewa Kubiak, 2018.

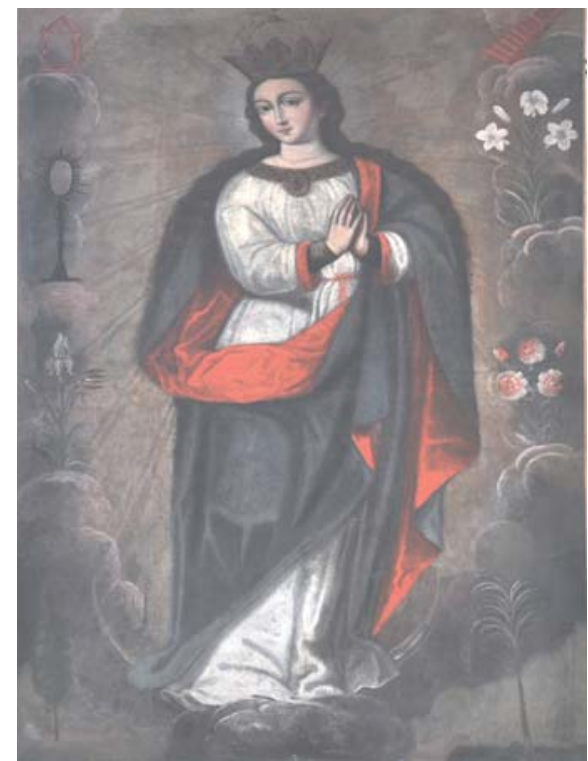

Fig. 11. Inmaculada Concepción (Tota Pulchra), anónimo, siglo XVIII, Capilla del Colegio de Santa Rosa de Lima en Cusco, fot. Ewa Kubiak, 2018.

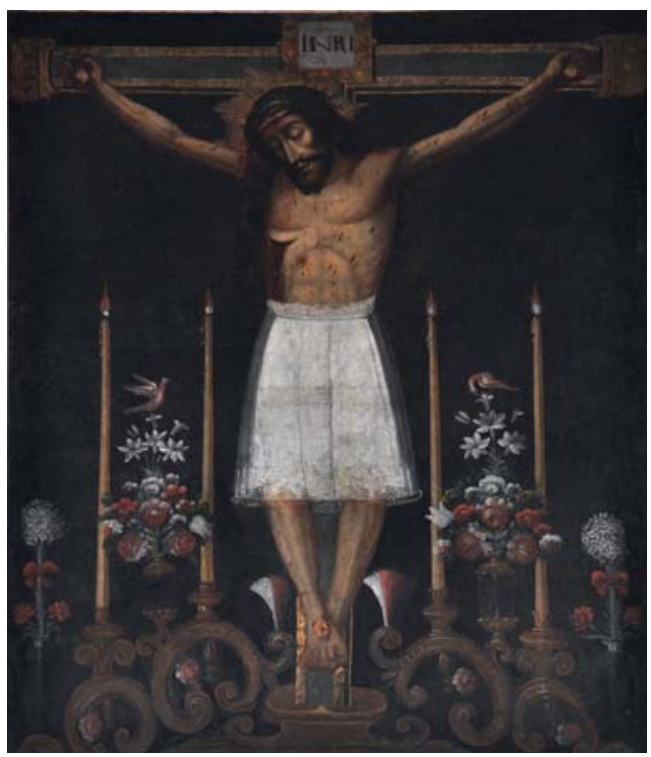

Fig. 13. Señor de los Temblores, anónimo, siglo XVIII, Capilla del Colegio de Santa Rosa de Lima en Cusco, fot. Ewa Kubiak, 2018. 


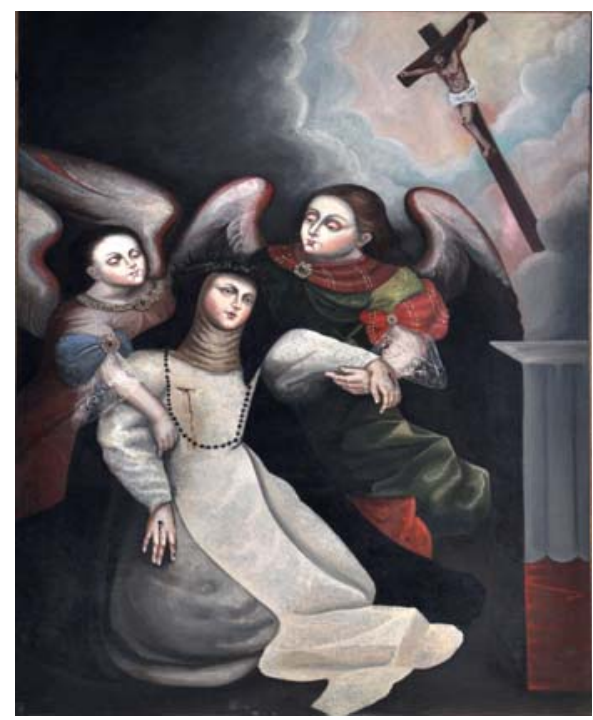

Fig. 14. Estigmatización de Santa Catalina, anónimo, siglo XVIII, Capilla del Colegio de Santa Rosa de Lima en Cusco, fot. Ewa Kubiak, 2018.

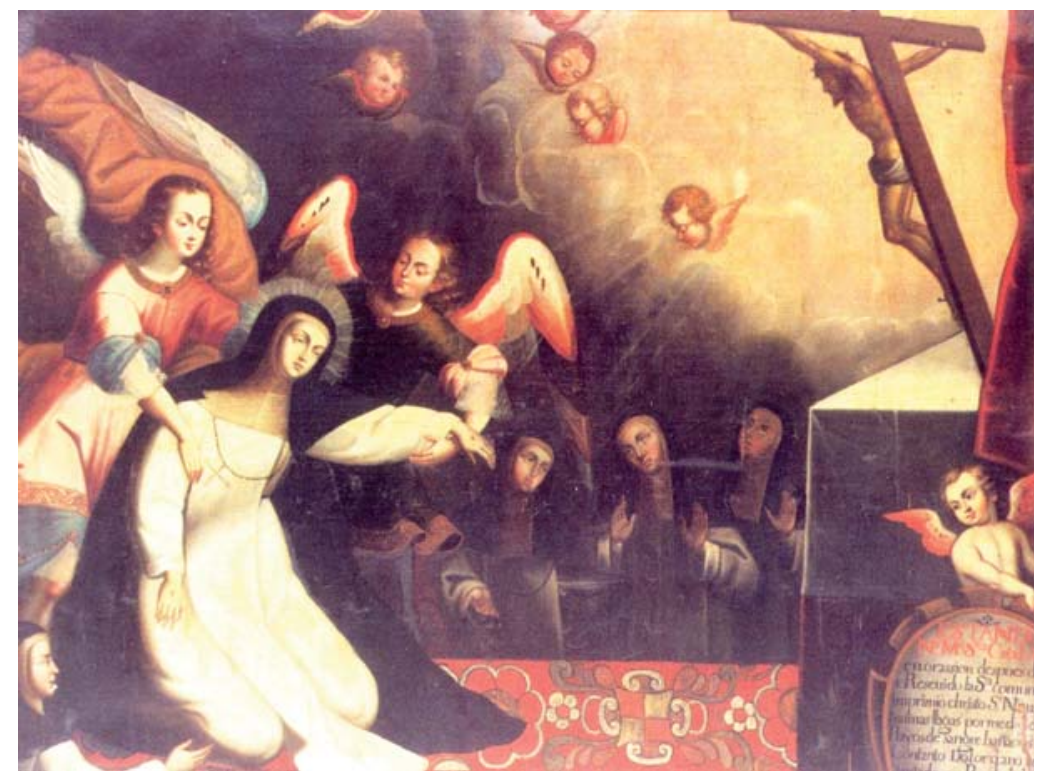

Fig. 15. Estigmatización de Santa Catalina, anónimo, el siglo XVII, escuela cusqueña, Monasterio de Santa Catalina de Siena de Córdoba, Argentina (Barbieri 2006: 159). 


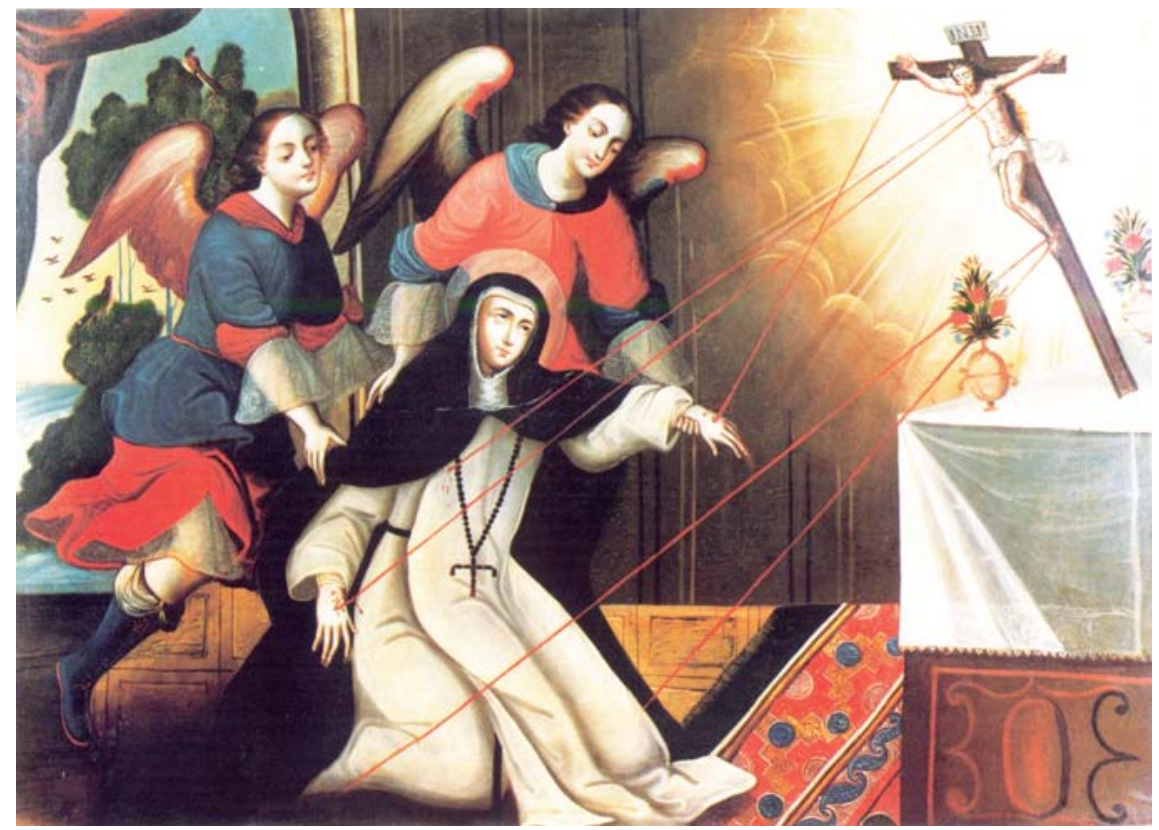

Fig. 16. Estigmatización de Santa Catalina, anónimo, el siglo XVIII, escuela cusqueña, Monasterio de Santa Catalina de Siena de Córdoba, Argentina (Barbieri 2006: 167).

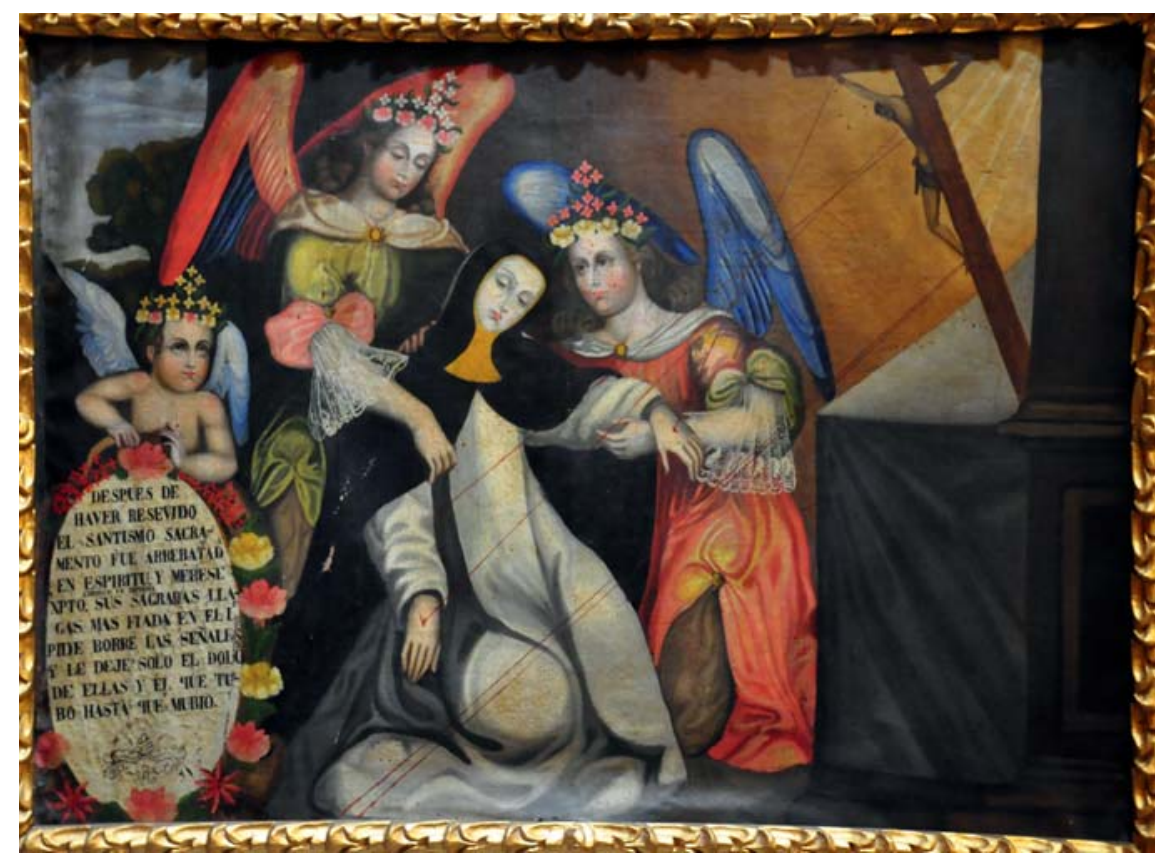

Fig. 17. Estigmatización de Santa Catalina, anónimo, segunda mitad del siglo XVII (con la inscripción del siglo XIX o XX), Monasterio de Santa Catalina de Siena, Arequipa, Perú, fot. Ewa Kubiak 2015. 


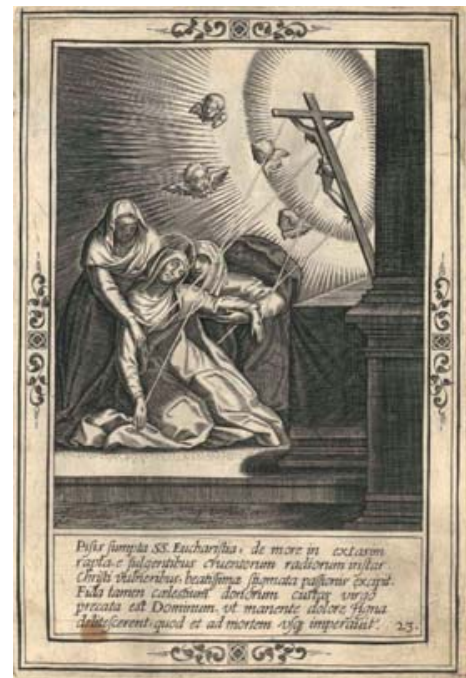

Fig. 18. Taller de Jean Leclerc IV, imagen 23 de 33 del libro: D. Catharinae 1607 (Biblioteca Nacional de España).

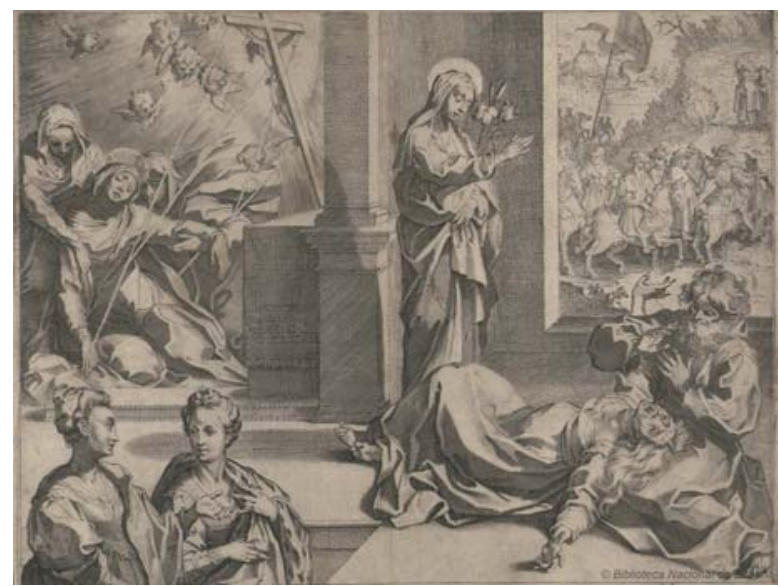

Fig. 19. Vida y milagros de Santa Catalina de Siena, Francesco Vanni y Pedro de Jode, 1597 (Biblioteca Nacional de España).

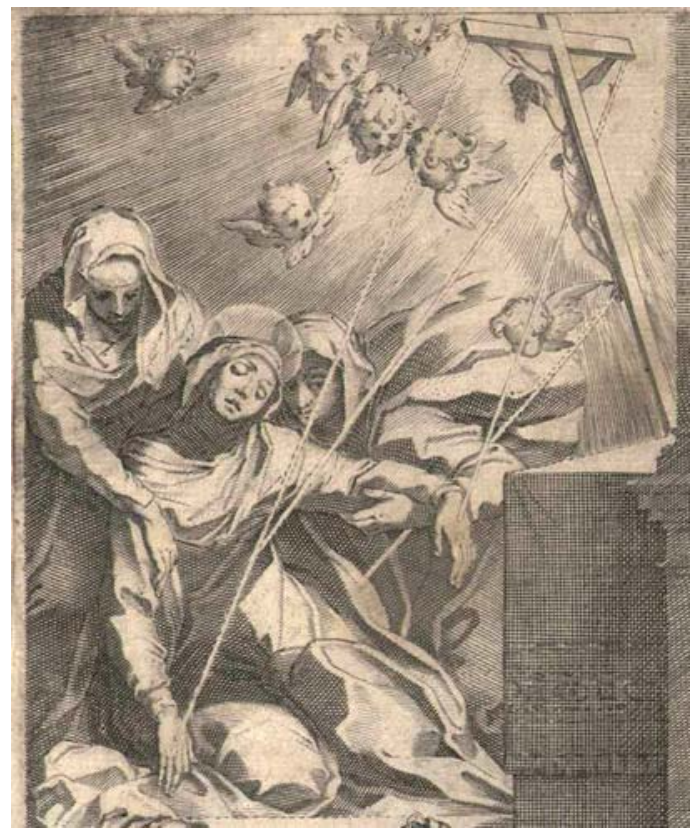

Fig. 20. Estigmatización de Santa Catalina, detalle de Vida y milagros de Santa Catalina de Siena, Francesco Vanni y Pedro de Jode, 1597 (Biblioteca Nacional de España). 


\section{Notas}

1 El estudio de la autora sobre el arte colonial en Cusco se llevó a cabo gracias a su estancia en Cusco (Perú) en el Centro de Estudios Andinos de la Universidad de Varsovia en el Cusco (CEACUV), que en 2018-2019 abarcaría en suma más de medio año. Me gustaría agradecerle al jefe del centro, profesor Mariusz Ziółkowski, por su apoyo, que me ha permitido continuar con mi labor de investigación, así como también a Dominika Sieczkowska, quien me ha prestado su ayuda en todos los asuntos relacionados con la organización.

2 Se hace difícil precisar el significado del término "beata", debido a la naturaleza no del todo formal de las comunidades a las que pertenecían. La entrada "beata" la encontramos en el diccionario de Girolamo Vittori (1609) con la explicación "devota, pia, religiosa" (1609: 97). Definiciones que se relacionan más cercas a nuestras investigaciones aparecen dos años más tarde. Dos términos "beata" y "beaterio" se encuentran en el diccionario de Sebastián de Covarrubias, Tesoro de la lengua castellana o española. Según esta publicación "beata" es "muger en abito religioso, que fuera de la comunidad en su casa particular professa el celibatu, y vive con recogimiento, ocupándose en oración, y en obras caridad" y "beaterio" es "la casa donde se recogen las beatas" (1611: 254-255). También un siglo más tarde, en el primer diccionario de la Real Academia Española podemos leer las definiciones parecidas, aunque más amplias: "Beata. f.f. Muger que viste hábito Religioso y professa celibato, y vive con recogimiento, ocupándose en oración y obras de charidád, y siguiendo la regla que más se acomoda a su genio, aunque no en Comunidad. En algunas partes como en Madrid, en la Casa que llaman de San Joseph, no solo viven estas Beatas en Comunidad, sino también guardan clausura. En otros, aunque viven en la Comunidad no la guardan, como en Alcalá. Llámanse Beatas por ampliación del Latino Beatus, a, um." Y "Beaterio. [...] La casa o lugar donde viven la[s] Beatas que forman comunidad, y tienen regla". (1726: 582-583). Actualmente, en el Diccionario de la Real Academia de la Lengua Española aparecen numerosas definiciones bajo este mismo vocablo. La más obvia es la referida a una persona beatificada por el Papa. Sin embargo, también se dan definiciones relacionadas con el funcionamiento de agrupaciones informales de mujeres. Beata es por lo tanto: "persona que lleva el hábito religioso sin vivir en comunidad ni seguir regla determinada", o "mujer que vive con otras en clausura o sin ella bajo cierta regla" o "mujer que con hábito religioso se emplea en pedir limosna o en otro tipo de menesteres en nombre de la comunidad a la que está agregada", DRAE Diccionario de la Real Academia Española, 23a edición, contraseña: "beato / beata", www.dle.rea.es, fecha de acceso: 24.10.2019].

3 Los beaterios fueron opciones más libres si los comparamos con los monasterios. Estas instituciones ostentaban también funciones sociales muy importantes. Nancy E. van Deusen escribe: "Como práctica institucional, el recogimiento involucraba a un número significativo de mujeres y niñas llamadas recogidas, que vivían voluntaria o involuntariamente en conventos, beaterios, hospitales y colegios. Fundados en toda España y América Latina, los recogimientos cumplieron múltiples funciones como colegios, asilos o centros de depósito legal, respaldados por el Estado español, pero a menudo bajo la tutela de una orden religiosa. Ellos albergaban a mujeres y niñas de distinta condición social, desde huérfanas hasta colegialas criollas, desde prostitutas hasta las hijas mestizas de los conquistadores, desde mujeres indigentes hasta mujeres remediadas. Los recogimientos actuaban también como depósitos de mujeres llamadas divorciadas, que buscaban una anulación matrimonial o un divorcio - una separación permanente, sin que ninguna de las partes pudiera volver a casarse. También servían como residencia temporal durante la ausencia del marido, como cárceles o centros correccionales. Algunos funcionaban como colegios" (Van Deusen 2007 [2001]: 16).

4 También existían congregaciones semejantes cuyas mujeres miembros vivían en sus propios hogares.

5 Las publicaciones de Nancy E. van Deusen relacionadas al tema: 1987, 1990, 1997, 1999, 2007[2001], 2017; véase también Josefina Muriel (1974).

6 El Monasterio de Santa Clara no fue la primera fundación monástica de Cusco. Dominicanos, mercedarios y franciscanos ya habían funcionado con anterioridad en esta ciudad. Sin embargo, mientras que los conventos masculinos fueron fundados por grupos de religiosos enviados por sus respectivas sedes en España, el convento femenino de Santa Clara lo fue por iniciativa local. En muchos conventos peruanos de finales del siglo XVI, tanto mujeres españolas como mestizas 
hallaron refugio, pero dentro de la comunidad reinaba por lo general una división estricta entre las monjas españolas y mestizas. Estas últimas no tomaban los votos monásticos y, sobre todo, dicha institución les proporcionaba cuidado y educación. (Burns 2008 [1999]: 23). Por ende, la fundación de un convento de monjas en Cusco, destinada a crear una comunidad religiosa para mestizas, debería considerarse como una situación de índole excepcional. No solo constituía un lugar de atención para las mestizas, sino que también les ofrecía la posibilidad de avanzar del noviciado a la orden religiosa, para por fin sellarlo todo con los votos perpetuos. En 1560, la mayoría de las que "ingresadas" en el monasterio eran de origen mestizo (Burns 2008 [1999]: 23-25). Aproximadamente la mitad de ellas se quedarían en el convento y tomarían los votos, en tanto que las restantes únicamente permanecerían temporalmente en la comunidad, donde recibirían instrucción, para decantarse más tarde por la vida secular; aunque, a decir verdad, fueron sus propias familias las que decidieron por ellas y las derivaron hacia la vida en el mundo (Burns 2008 [1999]: 28). Por supuesto, la situación se vería sometida a cambios con el tiempo. Para empezar, en 1565 , se introdujo la norma por la cual "ninguna hija ilegítima de un hombre español y una india, u otra mujer no blanca, podría ser elegida abadesa durante veinticinco años, esto es hasta el 31 de diciembre de 1590" (Burns 2008 [1999]: 31).), si bien en 1590 ya era impensable que una mestiza fuese elegida superiora de un monasterio. Asimismo se estableció cierta división dentro de la orden: en una primera estructura monástica, la de más bajo nivel, se encontraban las "monjas de velo blanco", que podían ser españolas y mestizas; en cambio, un segundo grupo lo conformaban las "monjas de velo negro", que detentaban los cargos del monasterio y entre las cuales se elegía la abadesa, nivel accesible solo para las criollas (Burns 2008 [1999]: 35; véase también: Burns 1998: 5-44 y Navarro Linares 2012).

7 En Cusco durante la época colonial la regla carmelitana fue muy popular en la organización de los beaterios. Vale la pena mencionar, que en 1592 fue editado en España por Diego Martínez de Coria Maldonado Manual de las beatas y hermanos terceros, de la horden de la Siempre Virgen, y madre de Dios, Sancta María del Monte Carmelo (Sevilla). La mayoría de los beaterios estuvieron vinculados a las reglas carmelitas y franciscanas. Los recogimientos de las beatas dominicas no se crearon hasta el siglo XVII y se asociaron con la figura de la primera santa dominica: Santa Rosa de Lima.

8 La autora también recuerda los beaterios de Cusco en su artículo de 2019 (Viñuales 2019: 88-90).

9 Esta es la fecha de la muerte del autor.

10 Sobre el criollismo relacionado con la figura de Santa Rosa de Lima y su culto véase: Luis Miguel Glave (1993).

11 Mesa, Gisbert 1980, I: 128; Flores Araoz 1995: 249; véase también: Cornejo Bouroncle 1960: 103-104.

12 Sobre las representaciones de Santa Rosa de Lima: Mesa, Gisbert 1980, I: 91, 97, 252; y la pintura mural en la sala capitular del convento de Santa Catalina en Cusco:

13 Con la relación al siglo XIX es importante el documento del año 1853 titulado "Comunicación enviada al Señor Gobernador Eclesiástico, Provisor y Vicario General del Obispado, indicando, concurrir y cumplir con los requisitos de la Fiesta de Santa Rosa de Lima” (AAC, 1853). Quiero agradecer a Donato Amado Gonzales, quien me anima a continuar con los estudios cusqueños y siempre encuentra tiempo para ayudarme, explicarme las dudas que tengo y orientarme en las fuentes de estudios. En este caso me ayudó encontrar una parte de los documentos del Archivo Regional del Cusco.

14 El libro es una recopilación de documentos hallados entre protocolos notariales en el Archivo Regional del Cusco (anteriormente Archivo Departamental del Cusco) relacionados con intervenciones artísticas, ampliamente entendidas, en la ciudad y su región durante el período colonial. También se las menciona Covarrubias Pozo (1958: 69).

15 Durante el siglo XVIII en el mundo hispanoamericano surgieron muchos beaterios bajo la advocación de Santa Rosa. Se podrían mencionar los recogimientos de mujeres en Puebla (México) (Neff 2017: 54-62)), Antigua Guatemala (Guatemala) (Valenzuela Morales 2013) y Manila (Filipinas) (Manchado López 1999: 485-512; Santander 2020: 189-204).

16 La división de beaterio en dos instituciones separadas refleja la estructura social del Cusco y los detalles del funcionamiento de los recogimientos en la ciudad andina.

17 Calculado a partir de la medida peruana: una vara y tres cuartos de vara. Una vara tiene unos $0,83 \mathrm{~m}$ de largo. 
18 J. M. Blanco recuerda al fundador del beaterio, Juan Hurtado, pero no a José Quintanilla (1974 [1834]: 249).

19 Esta fuente de inspiración está referida en la página del proyecto PESCA: https://colonialart.org/ archives/subjects/saints/individual-sAaints/catherine-of-siena\#c2914a-2914b, fecha de acceso: 24.10.2019].

20 La serie componen las estampas con varias escenas simultáneas de la vida de santa Catalina de Siena. La correspondencia entre el grabado y la composición pictórica es mencionada por Sergio Barbieri (2006: 159); véase también PESCA: https://colonialart.org/archives/subjects/saints/ individual-saints/catherine-of-siena\#c3115a-3115b, fecha de acceso: 24.10.2019].

21 Cada una de las instituciones posee la documentación mecanografiada en un único volumen. $\mathrm{He}$ podido leer las copias guardadas en la Biblioteca del Gobierno Regional de Cusco (Biblioteca del Gobierno Regional - Cusco), con sede en el Colegio Inca Garcilaso de la Vega en Cusco.

\section{Fuentes manuscritas}

\section{AAC Archivo Arzobispal del Cusco}

1788 AAC, Periodo Colonial, Sección órdenes religiosas, Signatura: LIV, 2, 25, La Hermana Juana del Sacramento de Santa Rosa, pide se ordene al Padre Predicador Hermenegildo Enríquez Camargo le entregue la imagen de San Josef y su retablo que están en el Beaterio de Callejón del Convento de Santo Domingo, para llevar a su Beaterio, dado que ella pago su hechura y allá no lo cuiden ni veneran, pp.1-4.

1826 AAC, Periodo Colonial, Sección visitas, Signatura: XVII, 4, 66, Razón de las rentas y número de religiosas de los Recogimientos de Nazarenas, el Carmen de San Blas, Beaterio de Belén Santa Rosa, pedida por el gobernador eclesiástico, 1826, [sin paginación].

1853 AAC, Época Colonial, Correspondencia, Signatura: XII, 5, 82, Comunicación enviada al Señor Gobernador Eclesiástico, Provisor y Vicario General del Obispado, indicando, concurrir y cumplir con los requisitos de la Fiesta de Santa Rosa de Lima.

ARC Archivo Regional del Cusco

1678

ARC, Sección Notarial, el siglo XVII, Escribanos varios, Legajo 315, 1677-1705, Obligación de Francisco Guari Lloclla, natural de la Parroquia de Santa Ana, f. 110.

1694 ARC, Sección Notarial, el siglo XVII, Escribano Joan de Saldaña, Legajo 303, 1694, Concierto. Marcos de Rivera maestro pintor residente en esta ciudad, se obliga hacer y pintar 13 lienzos de diferentes hechuras de Santos que irán declarados a satisfacción del padre Joseph Manuel de Elguita de la Comania de Jesus, rector del Colegio de San Borja, f. $186 \mathrm{r}$.

1701 ARC, Sección Notarial, el siglo XVIII, Escribano Cristóbal de Bustamante, Legajo 61, 1701, Testamento de Don Lázaro Ramos maestro cedero, residente en la Ciudad del Cuzco, f. 1191. 
1709 ARC, Sección Notarial, el siglo XVIII, Escribano Gregorio Basquez Serrano, Legajo 59, 1709, Concierto y oblig.[aci] ${ }^{o n}$ Don Diego Chipana con Petrona Rossa, ff. 436 r.-437 v.

1716 RC, Sección Notarial, el siglo XVIII, Escribano Felipe Arevalo y Ayala, Legajo 21, 1707-1713, Testamento de Doña Agustina Choque Sisa, f. 314.

1727 ARC, Colegio de Ciencias, Legajo 5, Cuaderno 3, Libro de Imventtarios de este nuestro Convento Hospital de Nuestra Señora de la Almudena formado de Nuestro Merced Reverendísimo Padre [...] Prefecto Generral Fray Miguel de la concepción, ff. 2r.-13v.

1738 ARC, Colegio de Ciencias, Legajo 5, Cuaderno 3, En este nuestro convento Betlemico Hospitalidad de Nuestra Señora de la Almudena de esta ciudad del Cusco en quince días del mes de enero de este presente año de mill cetecientos treinta y ocho (...), ff. 53r.-87v.

1772 ARC, Sección Notarial, el siglo XVIII, Escribano Juan Bautista Gamarra, Protocolo núm. 153, 1772-1774, Testamento de Don Agustín Bravo de Paredes, ff. 36v.- $48 \mathrm{v}$.

1813 ARC, Sección Notarial, el siglo XIX, Escribano Mariano Meléndez Páez, Protocolo núm. 184, 1812-1813, Imbentario extrajudicial de los bienes que quedarin por fin y muestre de D.[oñ] Martina Chihuantupa $y$ de la Paz, ff. 529r. -531r.

1819 ARC, Asuntos Eclesiásticos, Legajo 14, Exped.[ient] ${ }^{e}$ dela Fabrica dela Iglesia dela Parro.[qui] $]^{a}$ de S. [a] ${ }^{n}$ Geronimo, Inventario de ornamentos. (4 enero 1819), sin foliación.

AGN Archivo General de la Nación, Lima

1767-1768 AGN, Temporalidades Inventarios, Legajo 1, Cuaderno núm. 13. Testimonio de los autos $i$ diligencias que se siguieron para ocupar el colegio de la Transfiguración de los padres de la Compañia de Jesús, e inventarios que entonces se hicieron de los muebles y enseres del dicho Colegio, altares y ornamentos de su iglesia. $69 \mathrm{ff}$.

\section{Fuentes impresas}

Blanco

1974 [1834] Diario del viaje del presidente Orbegoso al sur del Perú editado, prólogo y notas por Félix Denegri Luna. vol. I-II. 319 pp. y 201 pp. Pontificia Universidad Católica del Perú. Instituto Riva-Agüero.

Castro, Ignacio de

1978 [1788] Relación del Cuzco editado por Carlos Daniel Valcárcel Esparza. 191 pp. Universidad Nacional Mayor de San Marcos, Lima.

Cornejo Bouroncle, Jorge

1960 Derroteros de arte cuzqueño. Datos para una historia del arte en el Peru. 338 pp. Editorial Garcilaso, Cuzco. 
Covarrubias, Sebastián de

1611 Tesoro de la lengua castellana o española. 1362 pp. Luis Sanchez, Madrid.

Cuzco 1689

1982 [1689] Cuzco 1689: documentos editado por Horacio Villanueva Urteaga. 508 pp. Centro de Estudios Rurales Andinos "Bartolomé de las Casas", Cuzco.

D. Catharinae

1607 D. Catharinae Senensis Virginis SSmae Ord. Praedicatorium Vita ac miracula selectiora formis aeneis expressa. Apud Ioannem le Clerc via S. Ioa: lateranensis ad insignem Salamandrae Regiae, Parisijs.

Diccionario 1726

1726 Diccionario de la lengua castellana, en que se explica el verdadero sentido de las voces, su naturaleza y calidad, con las phrases o modos de hablar, los proverbios o refrenes y otras cosas convenientes al uso de la lengua [...] Compuesto por la Real Academia Española. Tomo 1 (A-B). 723 pp. Imprenta de Francisco de Hierro, Madrid.

DRAE

2019 [2014] Diccionario de la Real Academia Española 23a edición, contraseña: "beato / beata", www.dle.rea.es, fecha de acceso: 24.10.2019].

Espinosa Medrano, Juan de

2011 [1695] Oración panegírica a la Gloriosa Santa Rosa, Patrona de los Reinos del Perú, en el Convento de Predicadores de esta gran Ciudad de el Cuzco, patente el Santísimo Sacramento. En Juan de Espinosa Medrano La novena maravilla con estudio preliminar Luis Jaime Cisneros y editado por Luis Jaime Cisneros y José A. Rodríguez Garrido pp. 249-256. Fondo Editorial del Congreso del Perú. Fondo Editorial del Banco de Crédito del Perú, Lima.

Esquivel y Navia, Diego de

1980 [c.1749] Noticias cronológicas de la gran ciudad del Cuzco editado por Félix Denegri Luna. Vol. II. 473 pp. Fundación Augusto N. Wiese, Banco Wiese Ltdo, Lima.

Martínez de Coria Maldonado, Diego

1592 Manual de las beatas y hermanos terceros, de la horden de la Siempre Virgen, y madre de Dios, Sancta María del Monte Carmelo. s.p. Fernando de Lara, Sevilla.

Meléndez, Juan

1671 Festiva Pompa, culto religioso, veneración reverente, fiesta aclamación, y aplauso a la feliz beatificación de la bienaventurada virgen Rosa de S. María, tercera del Orden de Predicadores, segunda Catalina Senense de la Iglesia. 120 ff. [sin editorial e imprenta] 1671. 
Paz Soldán, Mariano Felipe

1865 Atlas geográfico del Perú. 81 pp. Librería de Fermin Didot Hermanos, Hijos y Ca., Paris.

Unanue, Joseph Hipólito

1793 Guía política, eclesiástica y militar del Virreynato del Perú para el año de 1793 compuesta de orden del Superior Gobierno. 353 pp. Sociedad Academia de Amantes del País de Lima, Imprenta Real de los Huerfanos, Lima.

Vittorio, Girolamo

1609 Tesorode las tres lenguas francesa, italiana y española / Thresos des trois langues Françoise, italienne et espagnolle. 632 pp. Philipe Albert \& Alexandre Pernet, Ginebra.

\section{Referencias citadas}

Amado Gonzales, Donato

2003 De la casa señorial al beaterio Nazarenas. Revista Andina 36: 213-234.

Arias Cuba, Ybeth

2016 Desposorios místicos de santa Rosa de Santa María. Alianza monárquica con las Indias (siglos XVII-XVIII). Arte de América Latina 6: 81-116.

2019 Integración de un sistema devocional indiano en la Monarquía Hispana. El culto de santa Rosa de Santa María en las ciudades de Lima y México, 16681737. 636 pp. Tesis doctoral. Director de tesis: Dr. Óscar Mazín, México.

Barberi, Sergio

2006 Iglesia y monasterio de Santa Catalina de Siena de Córdoba, serie: $\mathrm{Pa}$ trimonio Artístico Nacional. Inventario de bienes muebles. 187 pp. Academia Nacional de Bellas Artes, The Getty Foundation, Buenos Aires.

Burns, Kathryn J.

1998 Gender and the Politics of Mestizaje: The Convent of Santa Clara in Cuzco, Peru. The Hispanic American Historical Review (1)78: 5-44.

2002 Beatas, “decencia” y poder: la formación de una elite indígena en el Cuzco colonial. En Incas e indios cristianos Elites indígenas e identidades cristianas en los Andes coloniales editado por Jean-Jacques Decoster. pp. 85-94. Centro de Estudios Regionales Andinos "Bartolomé de las Casas”, Institut Français d'Etudes Andines, Cuzco-Lima.

2007 Andean Women in Religion: Beatas, 'Decency' and the Defence of Honour in Colonial Cuzco. En Gander, Race and Religion in the Colonization of the American editado por Nora E. Jaffary. pp. 81-91. Asgate, Alderhot-Burlington.

2008 [1999] Hábitos coloniales. Los conventos y la economía espiritual del Cuzco. [traducción de Javier Flores Espinoza]. 308 pp. Quellca Centro de Estudios Andinos, Institut Français d'Etudes Andines, Lima. 
Busto Duthurburu, José Antonio del

2016 [2006] Santa Rosa de Lima. 356 pp. Fondo Editorial, Pontificia Universidad Católica del Perú, Lima.

Cantuarias Vargas, Ricardo

2002 Beaterios y monjíos en el Perú virreinal. Boletín del Instituto RivaAgüero 29: 65-80.

Cosio, José Gabriel

1918 El Cuzco Preispánico i colonial (contribución a su historia). 96 pp. Imprenta "El Trabajo", Cuzco 1918

Covarrubias Pozo, Jesús María

1958 Cuzco colonial y su arte: apuntes para la historia de los monumentos coloniales del Cuzco. 325 pp. H. G. Rozas, Cuzco.

Dean, Carolyn

2002 [1999] Los cuerpos de los incas y el cuerpo de Cristo. El Corpus Christi en el Cusco Colonial traducido por Javier Flores Espinoza. 253 pp. Fondo Editorial de la Universidad Nacional Mayor de San Marcos, Banco Santander Central Hispano, Lima.

Flores Araoz, José

1995 Iconografía de Santa Rosa. En Santa Rosa de Lima y su tiempo editado por José Flores Araoz, Ramón Mujica Pinilla, Luis Eduardo Wuffarden, Pedro Guibovich Pérez. pp. 213-302. Banco de Crédito del Perú, Lima.

Glave, Luis Miguel

1993 De Rosa y espinas. Creación de mentalidad criolla en los Andes (16001630). 26 pp. Instituto de Estudios Peruanos, Lima.

Herrera, Francisco Larco

1920 Beaterios Cuzco Histórico 1: 19-21.

Kubiak, Ewa

2020 El Beaterio de Nuestra Señora del Carmen a la luz del documento inédito de 1772 y la arquitectura actual del recogimiento [en imprenta].

Kubiak, Ewa y Juan Gómez Huacso

2019 La muerte simbólica. El cuadro con la representación de Silencio y Monja Crucificada del Beaterio del Carmen de San Blas en Cusco. Arte Kubler, George de América Latina/ Sztuka Ameryki Łacińskiej 9: 95-126.

1953 Cuzco. Reconstrucción de la ciudad y restauración de sus monumentos. Informe de la misión enviada por la Unesco en 1951. 45 pp. Unesco, Paris.

Manchado López, Marta M. ${ }^{\mathrm{a}}$

1999 El proyecto de convento de Santa Rosa de Lima, en Filipinas. Anuario de Estudios Americanos, LVI, 2: 485-512. 
Mesa, José y Teresa Gisbert

$1980 \quad$ Historia de la pintura cusqueña. Vol. I-II. 830 pp. Fundación Agusto N. Wiese, Banco Wiese Ldto., Lima.

Mujica Pinilla, Ramón

1995 El ancla de Santa Rosa de Lima: mística y política en torno a la Patrona de América. En Santa Rosa de Lima y su tiempo editado por José Flores Araoz, Ramón Mujica Pinilla, Luis Eduardo Wuffarden, Pedro Guibovich Pérez. pp. 53-211. Banco de Crédito del Perú, Lima.

2005 [2001] Rosa limensis. Mística, política e iconografía en torno a la patrona de América. 497 pp. Instituto Francés de Estudios Andinos, Centro Francés de Estudios Mexicanos y Centroamerocanos, Fondo de Cultura Económica, Lima.

Muriel, Josefina

$1974 \quad$ Los recogimientos de mujeres. Respuesta a una problemática social novohispana. 262 pp. Universidad Nacional Autónoma de México. Instituto de Investigaciones Históricas, México.

Navarro Linares, Deysi

2012 El convento de Santa Clara y la mujer mestiza cusqueña. Asesor doctor Jorge E. Escobar Medrano. Tesis auspiciada por el consejo de InvestiNeff, Franziska gación de la Universidad Nacional de San Antonio Abad.

2017 Arquitectura de los conventos femeninos de Puebla de los Ángeles a medidas del siglo XVIII: un acercamiento desde las fuentes documentales. Boletín de Monumentos Históricos, tercera época, 39: 53-81.

Peralta, Manuel José

1860 El terremoto de 28 de octubre de 1746. La Revista de Lima, 1: 744745 .

Perilli, Carmen

2011 El Doctor Lunarejo y la Rosa Indiana. Criollismo y religión en un sermón barroco del siglo XVII. Cuadernos del CILHA, año 12, 15: 19-28.

Santa Teresa, Higinio de

1967 Primer Beaterio Carmelitano en el País Vasco. Monte Carmelo 75: 230282.

Santander, Kathryn

2020 Constituciones and Rules of Beatas Indias (1726). En The Spanish Pacific, 1521-1815 editado por Christina H. Lee, Ricardo Padrón. pp. 189204. Amsterdam University Press, Amsterdam.

Valenzuela Morales, Dunia

2013 Templo del Beaterio de Santa Rosa de Lima. Proyecto de restauración y nuevo uso. Tesis de maestría en la Facultad de Arquitectura, en Restauración de Monumentos, Especialidad de Bienes Inmuebles y Centros 
Históricos. Asesor de tesis Mario Ceballos Espigares. Universidad de San Carlos de Guatemala. Antigua Guatemala.

Van Deusen, Nancy E.

1987 Dentro del cercado de los muros: el recogimiento en la época colonial. 38 pp. Centro de Documentación sobre la Mujer, Lima.

1990 Los primeros recogimientos para doncellas mestizas en Lima y Cuzco, 1550-1580 Allpanchis 35-36: 249-292.

1997 Instituciones religiosas y seglares para mujeres en el siglo XVII en Lima. En manifestaciones religiosas en el mundo colonial americano editado por Clara García Ayluardo, Manuel Ramos Medina. pp. 207230. Instituto Nacional de Antropología e Historia, Centro de Estudios de Historia de México, Universidad Iberoamericana, México.

1999 Manifestaciones de la religiosidad femenina en el siglo XVII: las betas de Lima. Histórica XXIII, 1: 47-78.

2007 [2001] Entre lo sagrado y lo mudano. La práctica institucional y cultural del recogimiento en la Lima virreinal. 330 pp. Institut français d'Etudes Andines, Fondo Editorial de Pontificia Universidad Católica del Perú, Lima.

2017 Embodying the sacred: women mystics in seventeenth-century Lima. 272 pp. Duke University Press, Durham.

Vélez Marquina, Elio

$2010 \quad$ Rosa de Indias: discursividad criolla y representación simbólica de la comunidad de Lima en Vida de Santa Rosa de Santa María del Conde de la Granja (1711). 272 pp. Tesis de licenciatura. Asesor: doctor José Antonio Rodríguez Garrido, Pontificia Universidad Católica del Perú.

Viñuales, Graciela María

2004 El espacio Urbano en el Cusco colonial uso y organización de las estructuras simbólicas. 213 pp. Centro de Documentación de Arquitectura Latinoamericana, Lima.

2019 Beaterio: entre convento y colegio. En Barroco. Naturaleza y paisaje editado por Paola Maurizio, María Cecilia Avegno. pp. 87-96. Unión Latina, La Paz.

Zárate, Rosario

1921 El Cuzco y sus monumentos. 80 pp. Sanmarti y Cia. Impresores, Lima.

Wuffarden, Luis Eduardo

1996 La serie del Corpus Christi: historia, pintura y ficción en el Cusco del siglo XVII. En La procesión del Corpus en el Cuzco editado por Luis Eduardo Wuffarden. pp. 27-72. Unión Latina. Fundación El Monte. Universidad de la Rábiola, Sevilla.

2008 Las visitas del obispo Mollinedo y sus políticas visuales: una fuente para la historia del arte colonial andino. En Sociedad y gobierno episco- 
pal: las visitas del obispo Manuel de Mollinedo y Angulo (Cuzco 16741694) editado por Pedro M. Guibovich y Luis Eduardo Wuffarden. pp. 41-67. Institute français d'études andines, Lima.

\section{Páginas de internet}

https://www.santarosa.edu.pe/institucion/nuestra-historia (fecha de acceso: 24.10.2019).

http://www.portalweb.santarosacusco.edu.pe/nosotros/resena (fecha de acceso: 24.10.2019)

https://colonialart.org (fecha de acceso: 24.10.2019) 